\title{
Reactor systems for syngas fermentation processes: a review
}

\author{
Asimakopoulos, Konstantinos; Gavala, Hariklia N.; Skiadas, loannis V.
}

Published in:

Chemical Engineering Journal

Link to article, DOI:

10.1016/j.cej.2018.05.003

Publication date:

2018

Document Version

Peer reviewed version

Link back to DTU Orbit

Citation (APA):

Asimakopoulos, K., Gavala, H. N., \& Skiadas, I. V. (2018). Reactor systems for syngas fermentation processes: a review. Chemical Engineering Journal, 348, 732-744. https://doi.org/10.1016/j.cej.2018.05.003

\section{General rights}

Copyright and moral rights for the publications made accessible in the public portal are retained by the authors and/or other copyright owners and it is a condition of accessing publications that users recognise and abide by the legal requirements associated with these rights.

- Users may download and print one copy of any publication from the public portal for the purpose of private study or research.

- You may not further distribute the material or use it for any profit-making activity or commercial gain

- You may freely distribute the URL identifying the publication in the public portal

If you believe that this document breaches copyright please contact us providing details, and we will remove access to the work immediately and investigate your claim 


\section{Accepted Manuscript}

Review

Reactor systems for syngas fermentation processes: a review

Konstantinos Asimakopoulos, Hariklia N. Gavala, Ioannis V. Skiadas

PII:

S1385-8947(18)30790-3

DOI:

https://doi.org/10.1016/j.cej.2018.05.003

Reference:

CEJ 19019

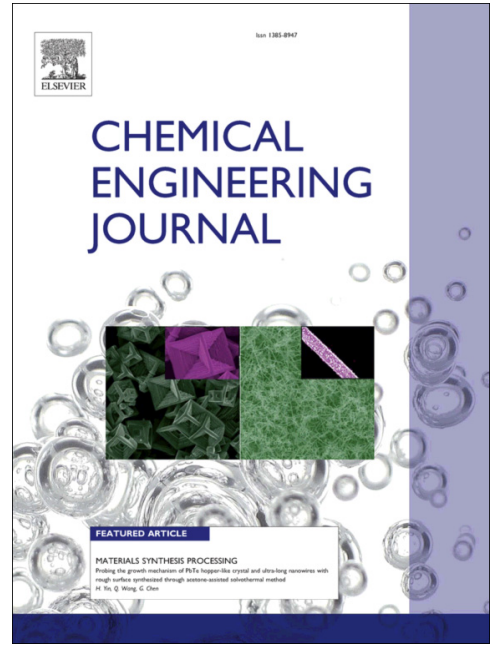

To appear in:

Chemical Engineering Journal

Received Date:

12 March 2018

Revised Date:

28 April 2018

Accepted Date:

1 May 2018

Please cite this article as: K. Asimakopoulos, H.N. Gavala, I.V. Skiadas, Reactor systems for syngas fermentation processes: a review, Chemical Engineering Journal (2018), doi: https://doi.org/10.1016/j.cej.2018.05.003

This is a PDF file of an unedited manuscript that has been accepted for publication. As a service to our customers we are providing this early version of the manuscript. The manuscript will undergo copyediting, typesetting, and review of the resulting proof before it is published in its final form. Please note that during the production process errors may be discovered which could affect the content, and all legal disclaimers that apply to the journal pertain. 


\title{
Reactor systems for syngas fermentation processes: a review
}

\author{
Konstantinos Asimakopoulos ${ }^{\mathrm{a}}$, Hariklia N. Gavala ${ }^{\mathrm{a}}$, Ioannis V. Skiadas ${ }^{\mathrm{a},}$ \\ ${ }^{a}$ Department of Chemical and Biochemical Engineering, Technical University of Denmark, Søltofts Plads
} 229, 2800 Lyngby, Denmark

*Corresponding author Email address: ivsk@kt.dtu.dk ; ioannis_sk@yahoo.co.uk

\author{
$\underline{\text { Highlights }}$
}

- Operation principles of the main bioreactor configurations in syngas fermentation

- Operational parameters maximizing bioreactors' productivities

- Comparison of the mass transfer efficiency of different bioreactor setups

- Current status in commercialization of syngas fermentation

\begin{abstract}
Implementation of biofuels as an alternative to fossil fuels has been established as an answer to climate change by limiting GHG emissions. Syngas fermentation has emerged as a promising process for the conversion of waste biomasses to valuable products with bioethanol being on the main focus. However, the bottleneck of the mass transfer of syngas compounds $\mathrm{H}_{2}$ and $\mathrm{CO}$ along with low production yields has set barriers to the development of an industrial scale plant. Recent research indicates that many different methodologies spring up in order to face this important challenge. The aim of this review is to assemble all these techniques applied in syngas fermentation, focusing on the different bioreactor configurations
\end{abstract}


operated in continuous mode for the production of liquid and gas biofuels. This article also outlines the so far entrepreneurial initiatives and the progress made towards the commercialization of the process.

Keywords: Synthesis gas, Syngas Fermentation, Bioreactor Configurations, Biochemicals, Biofuels, Mass Transfer

\section{Introduction}

The continuous increase of global energy needs due to the constant rise of global population and the intensification of industrial activities renders the use of renewable energy necessary $[1,2]$. Not only because of the gradual depletion of fossil fuel reserves, but also because humanity has to confront the major problem of the greenhouse effect and the resulting global warming [3-5]. Towards this direction, syngas fermentation to biofuels has gained increasing scientific attention as an alternative methodology for the production of renewable energy over the last decade [6-17].

Syngas or synthesis gas is a mixture of gases (mainly $\mathrm{CO}, \mathrm{CO}_{2}$ and $\mathrm{H}_{2}$ ) that can be produced from the gasification of biomass. The proportion of each gas depends on the type of the biomass used as a feedstock, the configuration of the gasifier and the operational parameters of the gasification process [18]. The industrially used gasification technology primarily includes fixed bed and fluidized bed gasifiers and the gas effluent often undergoes additional cleaning processes before it is fed to a reactor [19]. There is also on-going research on the optimization of the gasification process and novel technologies are often introduced [20-23].

Furthermore, syngas is quite enthralling from an environmental point of view because to-date it remains an important by-product of several industrial processes such as steel milling, petroleum refining, steam reforming and others involving combustion and partial oxidation. European Union has set a long-term target (2050) to decrease its greenhouse gas emissions by 80-95\% compared to 1990 [24] and in order to achieve that, exploitation of inorganic carbon sources is bound to have a fundamental role. Integration of 
syngas producing industrial activities and syngas fermentation units in a pre-commercial stage has already been attempted for bioethanol production in China [25].

Conventional catalytic processes for the production of liquid fuels like Fischer-Tropsch (FT) present high operational costs as they require high temperatures and pressures, high supply cost for the catalysts, fixed $\mathrm{H}_{2} / \mathrm{CO}$ ratios and pretreatment of the gaseous mixture for the removal of compounds that are poisonous to the catalysts [26]. Those disadvantages highlight the need for alternative ways to be sought. One promising alternative is the combination of thermochemical and biological processing of biomass[27]. The greatest merits of the fermentation processes are the mild conditions needed that entail low energy and infrastructure costs along with the high selectivity of the microbes. Apart from that, the biocatalysts (microbes) are cheap, they do not demand fixed $\mathrm{H}_{2} / \mathrm{CO}$ ratio and the process is odorless. In addition, health hazards are precluded and environmental pollution is markedly abated [28]. However, syngas bioconversion to liquid fuels faces important challenges that should be circumvented before the process is scaled up. The main issues are the mass transfer of sparingly soluble syngas compounds $\left(\mathrm{CO}_{2} \mathrm{H}_{2}\right)$ to the water-based microbial cultures and the relatively low growth rate of the microbes that leads to relatively low productivity rates [29].

The bottlenecks of syngas fermentation have been perceived since three decades ago but, because of the use of alternative methodologies for the production of liquid fuels such as fermentation of sugars or gasification and FT, little effort was given to surpass them up to the last decade. Concisely, the bioreactor setups for syngas fermentation that are dominant in the literature are continuous stirred tank reactors (CSTR) and membrane reactors. However, often new ideas spring up due to limitations and challenges those two main configurations have. CSTRs demand a lot of energy consumption for high agitation speeds so as to increase gas-to-liquid mass transfer [30] and, on the other hand membrane bioreactors, where biofilm formation takes place, face fouling issues from high cell concentrations and cell washout phenomena at high hydraulic dilution rates [31]. 
A key targeted product of the combined biomass gasification - syngas fermentation process is bioethanol due to its high octane number that allows it to be used in fuel blends in the transportation sector. Today bioethanol is produced in a commercial scale through the fermentation of carbohydrates deriving mainly from corn, sugarcane, sugarbeet and wheat. It is, however, highly debated that these crops, which can also be a source of food in a world that has not eliminated hunger, should play a major role in bioethanol production. This conflict rose extensive research towards second generation bioethanol (2GB) produced from lignocellulosic biomass that cannot be used as a food source [32]. The key step for the production of $2 \mathrm{~GB}$ is the pretreatment of the biomass, so as to break down the lignocellulosic structure and make cellulose and hemicellulose more amenable to the subsequent enzymatic hydrolysis step. Dependent on the type of the biomass many different pretreatment approaches have been studied (most common are: acid pretreatment, alkaline pretreatment, wet oxidation, organosolv pretreatment, ozonolysis, steam explosion, ammonia fiber explosion and biological treatment) each of them facing different economic and environmental drawbacks [33]. The main advantage of the thermochemical - biological processing is that the whole organic material of the lignocellulosic biomass (including lignin and hemicellulose) can be converted to hydrogen, carbon dioxide and carbon monoxide and then fermented to bioethanol, whereas in $2 \mathrm{~GB}$ production through hydrolysis, carbon in lignin and in a fraction of hemicellulose $(25-30 \%$ of the total feedstock carbon) cannot be utilized resulting thus in lower yields. In addition to that, the syngas fermentation platform is more flexible since it can process simultaneously waste gases from other sources besides lignocellulosic biomass [34].

Besides ethanol, other important products from the fermentation of syngas, are methane [8], acetic acid [10] and higher alcohols, i.e. butanol [35-37] and acids [11]. Methane is a valuable molecule for energy storage and can be utilized as a fuel for heat and electricity production as well as in Natural Gas Vehicle in the transportation sector. Acetic acid is an important precursor for the production of adhesives, inks, paints and coatings. It has also medical applications, for example, as an antiseptic against pseudomonas infections. Higher carbon chain VFAs such as propionic acid and butyric acid are used industrially as building 
blocks for the production of high added value chemicals and as additives for the preservation of food while butanol is mainly used as a solvent in many industrial applications. The aforementioned chemicals are principally produced chemically from fossil resources and, thus, there is high scientific interest on the possibility of sustainable biological production through syngas fermentation.

The aim of this review is to present the so far reported bioreactor configurations operated in continuous mode for the bioconversion of syngas to the abovementioned added value products and compare their effectiveness in achieving high productivity rates and high product concentrations.

\section{Basic Reactor Principles}

One of the most critical decisions to be considered for the growth of microorganisms is the configuration of the reactor that will be used as well as the operation mode of the process (continuous, batch, semicontinuous, combinations of processes). In an industrial scale several factors affect the final choice of the reactor and the operation mode, i.e. secondary products that may require the microorganisms to be in a stationary phase, genetic instability, toxicity of the desired product which results to inhibition of the microbes $[38,39]$.

The basic principle of stirred tank reactors is the agitation that leads to uniform conditions of concentration and temperature throughout the reactor volume. One agitator or more are mounted on a shaft which is connected to a gear box and a motor, used for the manipulation of the rotational speed. The power input for the rotation of the agitator is a crucial economic parameter that determines the economic sustainability of the bioprocess [40].

Bubble columns reactors (BCR) are cylindrical vessels, which are filled with a liquid phase, and a gas phase is supplied at their bottom. For the design of a bubble column attention should be payed to two factors: diameter to length ratio and the type of the gas sparger forming the bubbles. The gas is spread in the liquid volume of the column through convective flow which is driven by the incremental density differences 
$[41,42]$. An additional reactor configuration is the gaslift. Depending on their structure, gaslift reactors can be divided in two main categories; external loop and internal loop. The external loop airlift reactors consist of distinct conduits and the fluid flow is circulating from the one conduit to the other. On the other hand internal loop airlift reactors consist of concentric tubes and the fluid flow is circulating from the inner to the outer tube. In both configurations gas is sparged from the bottom of the reactor $[42,43]$.

Hollow fiber membrane reactors (HFR) are gas to liquid transfer membrane systems providing a high specific surface area. They can also serve as support for microbial growth and biofilm formation but special attention should be given to the thickness of the biofilm because it can also have a negative effect when microbial growth is high enough $[44,45]$. This phenomenon is called biofouling and a lot of research is currently applied towards illuminating its causes, so as to design more efficient reactors where biofouling can be limited and controlled $[46,47]$. In order to mitigate biofouling in membrane bioreactors several strategies have been attempted including both physical and chemical methods[48]. Depending on the application, the membranes can be either submerged to the liquid medium in the reactor or externally connected in series with the reactor [49-51]. Applications of various types of hollow fiber membrane modules have been reviewed by Kumar et al. [52].

Trickle bed reactors (TBR) consist of a packed bed column on which biofilm grows and gas is flowing cocurrently or counter-currently to the liquid [53]. The name of this type of reactors comes from the trickling of the liquid medium through the pores of the inert material and through the gaps amongst the inert material [54]. This kind of setups has been used for degradation of pollutants such as hydrogen sulfide, volatile organic compounds (VOCs), dichloromethane and ammonia [55-59].

\section{Mass Transfer Calculations under Abiotic Conditions}

Several bioreactor configurations can be found in the literature tested under abiotic conditions for the calculation of the mass transfer coefficient $\left(\mathrm{K}_{\mathrm{L}} \mathrm{a}\right)$ of syngas compounds to water. However, any comparison 
of the values of mass transfer coefficients reported in different publications should be done with caution because of the different methodologies used for the calculation of $K_{L} a$, the different ways of volume calculation (working volume, total volume, packed bed volume) and the different operational parameters tested [60]. A collection of reported $K_{L}$ a values and the operational conditions under which they were achieved can be seen in table 1.

One of the highest reported values of $K_{L} \mathrm{a}$ is $946 \mathrm{~h}^{-1}$ for a composite hollow fiber (CHF) membrane module made of polyethylene and polyurethane [61]. The inlet was pure $C O$ at a flow of $500 \mathrm{~mL} \cdot \mathrm{min}^{-1} \cdot \mathrm{L}_{\mathrm{RWV}}{ }^{-1}(\mathrm{RWV}=$ Reactor Working Volume) and the CHF module was operated without a gas outlet. In a similar configuration with hydrophobic polypropylene hollow fiber membranes, $\mathrm{K}_{\mathrm{L}}$ a for $\mathrm{CO}$ was calculated at $385 \mathrm{~h}^{-1}$ when a syngas composition of $50 \% \mathrm{CO}, 30 \% \mathrm{H}_{2}$ and $20 \% \mathrm{CO}_{2}$, and an inlet flow of $55.34 \mathrm{~mL} \cdot \mathrm{min}^{-1} \cdot \mathrm{L}_{\mathrm{RWV}}{ }^{-1}$ were applied [50]. It was also shown that higher gas supply rates, higher liquid recirculation rates and a bigger number of fibers result to the improvement of the mass transfer rate. When experiments were carried out with a gas-lift reactor coupled with a $20 \mu \mathrm{m}$ bulb diffuser and pure $\mathrm{CO}$ in the inlet at a flow of $1667 \mathrm{~mL} \cdot \mathrm{min}$ ${ }^{1} \cdot \mathrm{L}_{\mathrm{RWV}}{ }^{-1}$ the $\mathrm{K}_{\mathrm{L}}$ a value was $129.6 \mathrm{~h}^{-1}$ for CO [62]. In a previous experimental study, Munasinghe and Khanal reported values ranging from 0.4 to $91 \mathrm{~h}^{-1}$ for eight different bioreactor configurations tested under the same conditions [63].

Orgill et al. [60] compared the mass transfer coefficients of a trickle bed reactor, a hollow fiber membrane reactor and a stirred tank reactor under various gas flow and liquid flow rates. In that study the gas applied was air and the calculation of the $\mathrm{K}_{\mathrm{L}}$ a was determined through the \%DO (dissolved oxygen) in the liquid phase [60]. Regarding the trickle bed reactor, two different sizes of packing material were assessed (3 mm and $6 \mathrm{~mm}$ soda lime glass beads) and for the hollow fiber reactor, the effect of five different hollow fiber modules on mass transfer was examined. The maximum mass transfer values of the TBR, the HFR and the CSTR were 421, 1062 and $114 \mathrm{~h}^{-1}$ respectively. Finally, for a study regarding the type of the impeller 
employed in a CSTR the outcome was that improved mass transfer without increased power supply can be achieved with dual impeller schemes with an axial flow impeller as the top impeller [64]. 
Table 1. Mass transfer coefficient $\mathrm{K}_{\mathrm{L}}$ a calculated under abiotic conditions for several bioreactor configurations and operational parameters

\begin{tabular}{|c|c|c|c|c|c|c|c|}
\hline Reactor Configuration & $\begin{array}{l}\text { Gas } \\
\text { Composition }\end{array}$ & $\begin{array}{l}\text { Working Volume } \\
\text { (L) }\end{array}$ & $\begin{array}{l}\text { Packing or Hollow } \\
\text { Fiber Material }\end{array}$ & $\begin{array}{l}\text { Gas Flow } \\
\left(\mathrm{mL} \cdot \mathrm{min}^{-1}\right)\end{array}$ & $\begin{array}{l}\text { Agitation } \\
\text { (rpm) }\end{array}$ & $\mathrm{K}_{\mathrm{L}} \mathrm{a}\left(\mathrm{h}^{-1}\right)$ & References \\
\hline Hollow Fiber Membrane (HFMBR) & $\begin{array}{l}50 \% \mathrm{CO}, 30 \% \\
\mathrm{H}_{2} \text {, and } 20 \% \\
\mathrm{CO}_{2}\end{array}$ & $\begin{array}{l}\text { HFM 0.13, } \\
\text { Reservoir } 2.4\end{array}$ & $\begin{array}{l}\text { Hydrophobic } \\
\text { polypropylene }\end{array}$ & 140 & 90 (reservoir) & $\begin{array}{l}385 \\
\text { CO }\end{array}$ & [50] \\
\hline $\begin{array}{l}\text { Composite Hollow Fiber Membrane (CHF } \\
\text { module) }\end{array}$ & $99.99 \%$ CO & 3 & $\begin{array}{l}\text { MHF0504MBFT } \\
\text { (polyethylene and } \\
\text { polyurethane) }\end{array}$ & 1500 & & 946 & [61] \\
\hline Gas-Lift & $\begin{array}{l}>99.99 \% \text { purity } \\
\text { of } \mathrm{CO} \text { and } \mathrm{H}_{2} \text { in } \\
\text { each } \\
\text { experiment }\end{array}$ & 3 & NA & 5000 & NA & $\begin{array}{l}129.6 \mathrm{CO} \\
97.2 \mathrm{H} 2\end{array}$ & [62] \\
\hline Column with Column Diffuser & \multirow{6}{*}{$\begin{array}{l}99.99 \% \text { purity } \\
\text { of CO }\end{array}$} & \multirow{6}{*}{3} & \multirow{6}{*}{ NA } & \multirow{6}{*}{5000} & NA & 40 & \multirow{6}{*}{ [63] } \\
\hline Column with $20-\mu \mathrm{m}$ Bulb Diffuser & & & & & NA & 70.8 & \\
\hline Column only with Sparger & & & & & NA & 50.4 & \\
\hline Column with Sparger with Mechanical Mixing & & & & & 300 & 55.8 & \\
\hline $\begin{array}{l}\text { Column with Submerged Composite Hollow } \\
\text { Fiber Membrane }\end{array}$ & & & & & NA & 1.1 & \\
\hline Air-Lift Combined with Single Point Gas Entry & & & & & NA & 45 & \\
\hline \multirow{2}{*}{ Trickle Bed } & \multirow{6}{*}{ air } & \multirow{2}{*}{$\begin{array}{l}1 \text { (packed bed } \\
\text { volume) }\end{array}$} & $\begin{array}{l}3 \mathrm{~mm} \text { soda lime } \\
\text { glass beads }\end{array}$ & 130.9 & \multirow{2}{*}{ NA } & 171 & \multirow{6}{*}{ [60] } \\
\hline & & & $\begin{array}{l}6 \mathrm{~mm} \text { soda lime } \\
\text { glass beads }\end{array}$ & 106.4 & & 421 & \\
\hline \multirow{4}{*}{ Hollow Fiber } & & \multirow{4}{*}{$\begin{array}{l}5 \text { (water holding } \\
\text { tank) }\end{array}$} & $\begin{array}{l}\text { Hydrophilic porous } \\
\text { polystyrene }\end{array}$ & \multirow{4}{*}{$\begin{array}{l}1000-2000 \\
\text { (effect of } \\
\text { gas flow } \\
\text { was } \\
\text { considered } \\
\text { negligible) }\end{array}$} & \multirow{4}{*}{ NA } & 55 & \\
\hline & & & $\begin{array}{l}\text { Hydrophilic porous } \\
\text { polyether sulfone }\end{array}$ & & & 20 & \\
\hline & & & $\begin{array}{l}\text { Hydrophobic porous } \\
\text { polypropylene }\end{array}$ & & & 240 & \\
\hline & & & Hydrophobic non- & & & 1062 & \\
\hline
\end{tabular}




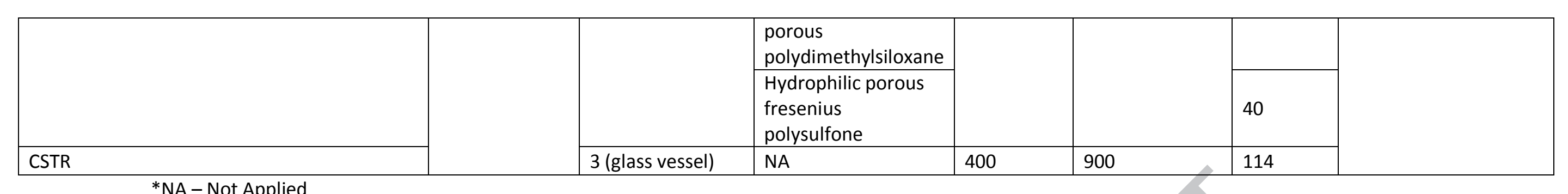

*NA - Not Applied 


\section{Continuous Processes}

\subsection{Production of Ethanol and/or Acetate}

Ethanol constitutes the main targeted product of syngas fermentation because of its availability for a wide spectrum of applications, hence several factors of the fermentation process have been studied and are in depth reviewed $[15,27,28,34,65-67]$. In short, the most crucial ones are: bioreactor configuration and operational parameters such as pressure, temperature and $\mathrm{pH}$. In addition the yield and the productivity of ethanol can be affected by the type of liquid media used, surfactants, even the use of nanoparticles [6877]. Regarding the effects of temperature on syngas fermentation, there has recently been an effort to enhance alcohol productivity and avoid acid crash phenomena by applying lower values than the optimum ones with positive results in batch experiments[78].

The majority of bioreactor configurations tested for the production of ethanol, or acetate as a precursor, is stirred tank vessels. Peptostreptococus productus was one of the first bacteria ever studied for the fermentation of syngas compounds to liquid fuels [79-81]. The maximum productivity of acetate measured was $4.8 \mathrm{mmol} \cdot \mathrm{L}_{\mathrm{RWV}}{ }^{-1} \cdot \mathrm{h}^{-1}$ with an agitation speed of $400 \mathrm{rpm}$ and a gas flow of $19.54 \mathrm{~mL} \cdot \mathrm{min}^{-1} \cdot \mathrm{L}_{\mathrm{RWV}}{ }^{-1}[79]$. Those results were promising and advocated to the continuation of experimental research over the subject. However, to our knowledge no other studies with P. productus (later classified as Ruminococcus productus [82] and finally as Blautia producta [83]) can be found in the literature for continuous syngas fermentation. The first $\mathrm{pH}$ based study for syngas fermentation was performed by Grethlein et al. [84] with bacterium Butyribacterium methylotrophicum in a CSTR set-up. The scientists observed that lowering the $\mathrm{pH}$ resulted in an alteration of the metabolism of $\mathrm{CO}$ towards more reduced products, which is quite critical since a route to alcohols' production opened. Researchers had earlier managed to produce acetate and butyrate with B. methylotrophicum [85-87]. 
Another landmark in the research of syngas fermentation is the introduction of microbubble sparging $[88,89]$. The researchers designated the augmented mass transfer of $\mathrm{CO}$ into the liquid phase when the gas phase was sparged in the form of microbubbles with a 5.5 times increase of the $K_{L}$ a value compared to conventional sparging ( $91 \mathrm{~h}^{-1}$ and $14 \mathrm{~h}^{-1}$ respectively). This was a rational observation since smaller bubbles have more beneficial surface/volume ratio [90]. The operational parameters were the same for both experiments and only the effect of the type of the sparger was tested. Acetate productivity from Butyribacterium methylotrophicum was measured at $2.71 \mathrm{mmol} \cdot \mathrm{L}_{\mathrm{RWv}}{ }^{-1} \cdot \mathrm{h}^{-1}$ which was less than the one with P. productus. A schematic of the bioreactor set-up, as it was reported from Bredwell et al. [88], is presented in Figure 1.

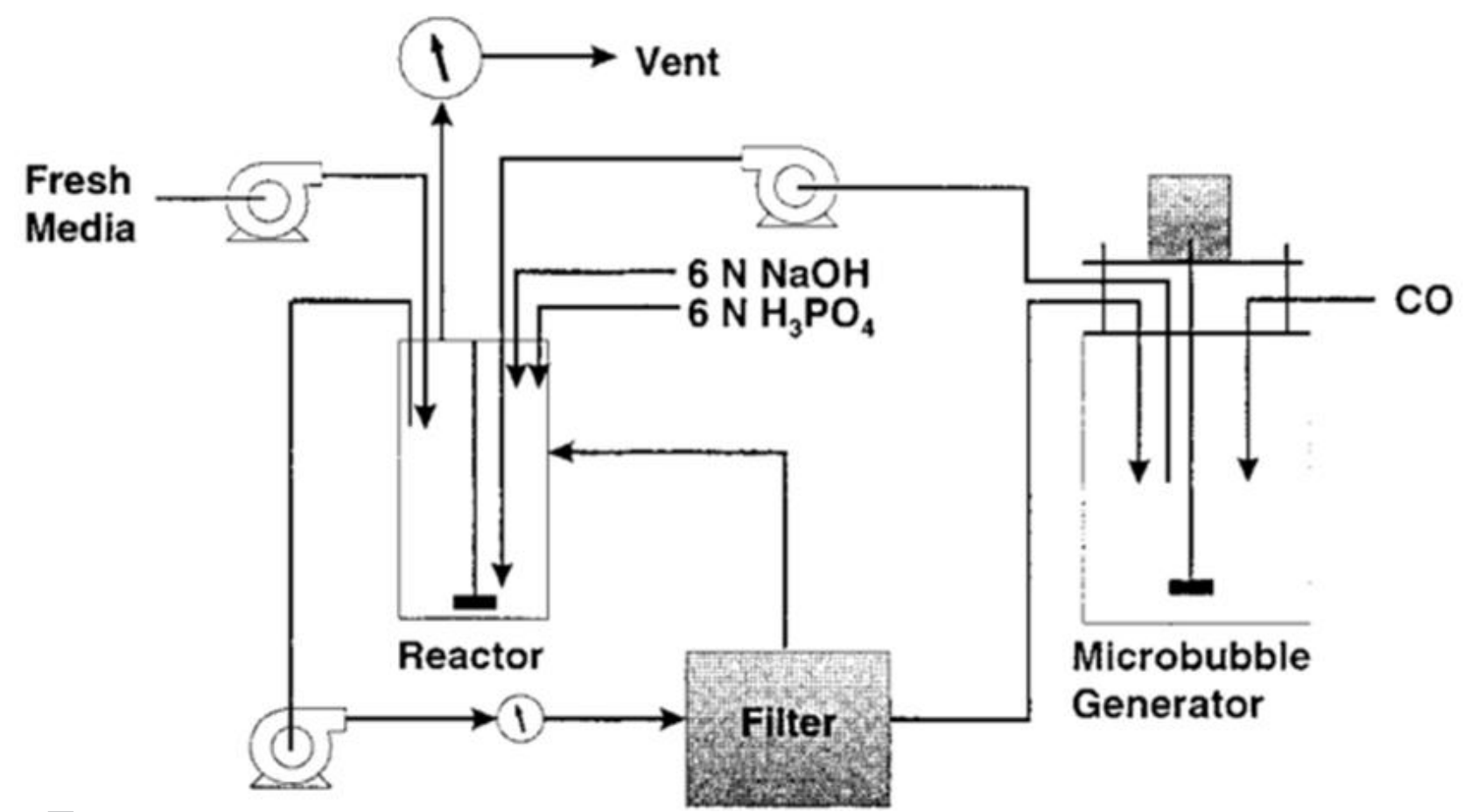

Figure 1. CSTR set-up with external microbubble generator [88]. The microbubble generator contained a spinning disc rotated at $4000 \mathrm{rpm}$ for the microbubble formation.

Chang et al. [75] used a bioreactor configuration (Figure 2) made up from a bubble column reactor and a hollow fiber membrane module as a cell recycle system. The purpose of the study was to ascertain Eubacterium limosum as a means of syngas conversion to liquid fuels under several CO partial pressures. 
The acetate productivity reached almost $3.65 \mathrm{mmol} \cdot \mathrm{L}_{\mathrm{RWv}}{ }^{-1} \cdot \mathrm{h}^{-1}$ and $\mathrm{K}_{\mathrm{L}}$ a was calculated at $72 \mathrm{~h}^{-1}$ with a CO partial pressure of $41.5 \mathrm{kPa}$.

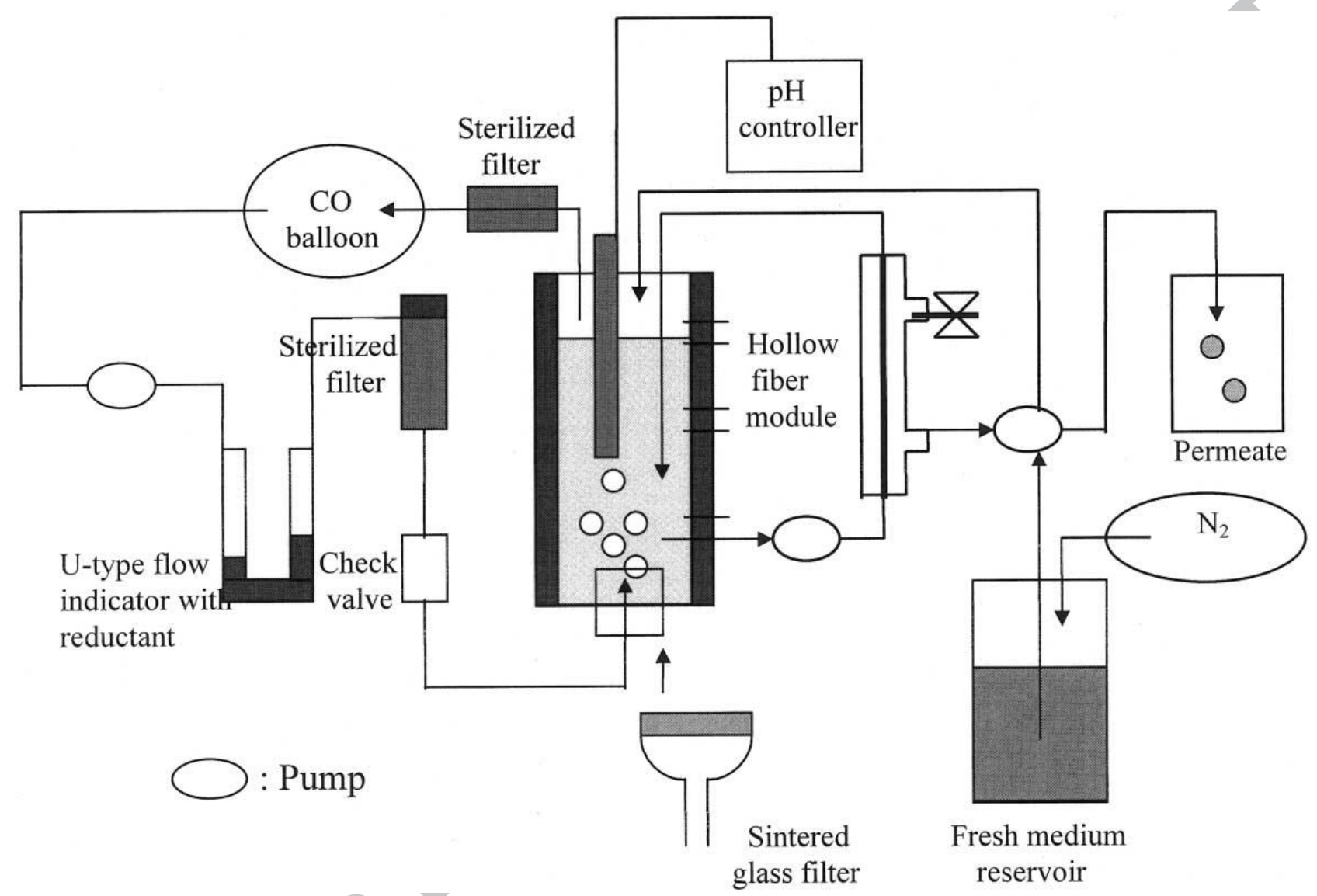

Figure 2. Schematic bioreactor set-up used by Chang et al. [75] for CO fermentation. CO was fed from the bottom of the bubble column with a gas recycle loop recirculating the non-converted $\mathrm{CO}$ in the top. The liquid media were stored in a reservoir vessel flowing into the bubble column from the top. Liquid recirculation was also employed with a hollow fiber membrane module.

A different approach to the bioconversion process of syngas to ethanol was given by Kundiyana et al. [77] and Richter et al. [91] by suggesting a two stage system where in the first stage microbial growth coupled to acetogenesis occurs while in the second phase solventogenesis takes place. Kundiyana et al. [77] used two CSTR fermentors connected in series and installed a hollow fiber membrane module for cell recycle in each fermentor. The flow of syngas was tested both in a co-current and a counter-current orientation. In the first case syngas was flowing from stage 1 reactor to stage 2 and in the second from stage 2 to stage 1. 
Conversely, Richter et al. [91] developed a setup with a CSTR and a bubble column reactor applying also a cell retention system and a gas recycle loop (Figure 3). Ethanol production was taking place in the bubble column at a productivity of $8.04 \mathrm{mmol} \cdot \mathrm{L}_{\mathrm{Rwv}}{ }^{-1} \cdot \mathrm{h}^{-1}$ and a concentration of $20.7 \mathrm{~g} \cdot \mathrm{L}^{-1}$ which is promising for this kind of systems as this value is much higher than single CSTR fermentation with $C$. ljungdahlii reported by Mohammadi et al. [92] and Younesi et al. [93] who achieved maximum titer of $6.5 \mathrm{~g} \cdot \mathrm{L}^{-1}$ and $11 \mathrm{~g} \cdot \mathrm{L}^{-1}$,

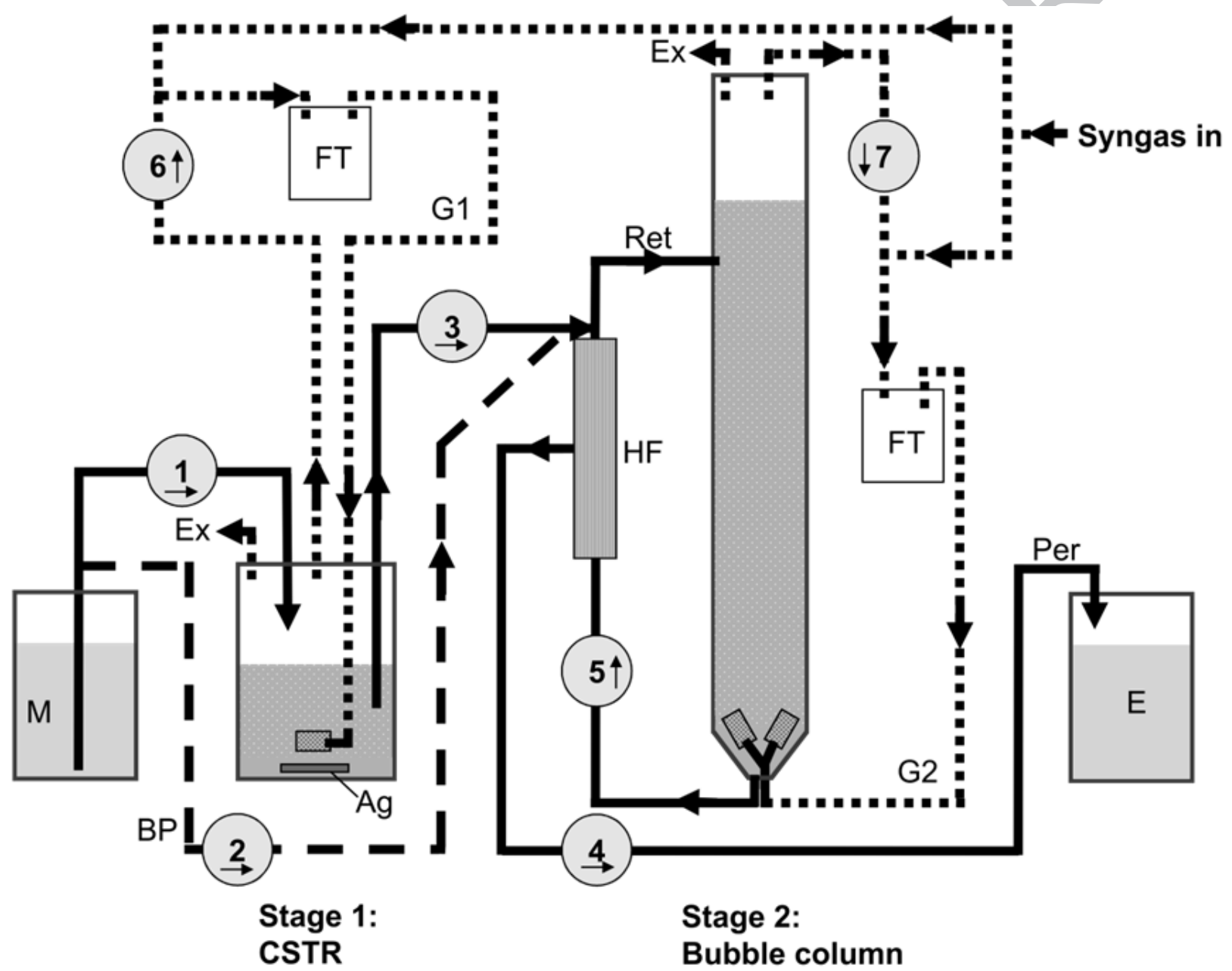

Figure 3. Two stage syngas fermentation to ethanol scheme by Richter et al. [91]. Solid lines represent the flow of the liquid media and dotted lines the flow of the gas phase. Abbreviations: Ag, agitation; BP, bypass; E, effluent reservoir; Ex, exhaust; FT, foam trap; G1, G2, gas recycle loops; HF, hollow fiber module for cell recycle; M, media reservoir; Per, permeate; Ret, retenate. Liquid media flowed to the CSTR from a reservoir vessel and subsequently were pumped to the bubble column. Recirculation of the liquid media was applied through a hollow fiber membrane module. The gas was sparged from the bottom of the bubble column and was recirculated for better conversion rates. Similarly, syngas was flowing to the agitated vessel. 
respectively. However the researchers reported $2 \%$ ethanol content in the effluent which is relatively low and demands advanced distillation techniques.

In order to overcome mass transfer limitations, Shen et al. [94-96] tested three biofilm formation modules in regard to their $\mathrm{K}_{\mathrm{L}} \mathrm{a}$ and ethanol productivity. The syngas composition $\left(20 \% \mathrm{CO}, 5 \% \mathrm{H}_{2}, 15 \% \mathrm{CO}_{2}\right.$, and $60 \%$ $\mathrm{N}_{2}$ ) and the biocatalyst (Clostridium carboxidivorans P7) was the same for all the experiments whereas the operational parameters were optimized for each case. First, a hollow fiber membrane module made of microporous hydrophobic polypropylene was tested [94]. The module was not submerged within the bioreactor, but instead, connected to an agitated reservoir vessel. Ethanol productivity was $3.12 \mathrm{mmol} \cdot \mathrm{L}_{\mathrm{RWV}}{ }^{-}$ ${ }^{1} \cdot h^{-1}$ with an ethanol to acetate ratio of 4.79 when the syngas flow, the liquid recirculation and the dilution rate were $37.5 \mathrm{~mL} \cdot \mathrm{min}^{-1} \cdot \mathrm{L}_{\mathrm{RWV}}{ }^{-1}, 25 \mathrm{~mL} \cdot \mathrm{min}^{-1} \cdot \mathrm{L}_{\mathrm{RWV}}{ }^{-1}$ and $0.96 \mathrm{~d}^{-1}$ respectively. Second, the author employed a cordierite-based ceramic monolith cylinder housed in a plexiglass column connected with an agitated reservoir vessel akin to the previous set up [95]. The confinements in the range of values of the operational parameters in this case are due to unwanted abrading and biofouling phenomena taking place in the biofilm. The maximum ethanol productivity of $2.13 \mathrm{mmol} \cdot \mathrm{L}_{\mathrm{RWv}}{ }^{-1} \cdot \mathrm{h}^{-1}$ was achieved at $37.5 \mathrm{~mL} \cdot \mathrm{min}^{-1} \cdot \mathrm{L}_{\mathrm{RWv}}{ }^{-1}$ syngas flow rate and $0.48 \mathrm{~d}^{-1}$ dilution rate. Ethanol to acetate ratio was measured at 2.1. A schematic of the reactor configuration is presented in Figure 4. The third set up was different from the previous ones: a horizontal mesh cage packed with AnoxKaldnes ${ }^{\mathrm{TM}}$ carriers was placed into a glass tank and was rotated by a gearmotor [96]. The rotated packed bed bioreactor provided a $45 \%$ cage submersion when the cage was in its vertical state to the surface of the liquid. Syngas was entrained in the liquid media through a submerged gas distributor in the bottom of the vessel. While the rotational speed of the gearmotor was $50 \mathrm{rpm}$, the headspace absolute pressure $29.7 \mathrm{psi}$ and the dilution rate $0.96 \mathrm{~d}^{-1}$, the productivity of ethanol reached $6.06 \mathrm{mmol} \cdot \mathrm{L}_{\mathrm{RWv}}{ }^{-1} \cdot \mathrm{h}^{-1}$ which was the highest amongst the configurations tested with the headspace pressure being a parameter affecting the productivity to a significant degree. 
Table 2. Bioreactor configurations for the production of ethanol and acetate

\begin{tabular}{|c|c|c|c|c|c|c|c|c|c|c|c|}
\hline $\begin{array}{l}\text { Reactor } \\
\text { Configuration }\end{array}$ & Gas Composition & $\begin{array}{l}\text { Working } \\
\text { Volume } \\
\text { (L) } \\
\end{array}$ & \begin{tabular}{|l|} 
Packing or \\
Hollow Fiber \\
Material \\
\end{tabular} & $\begin{array}{l}\text { Gas flow } \\
\left(\mathrm{mL} \cdot \mathrm{min}^{-1}\right)\end{array}$ & $\begin{array}{l}\text { Agitation } \\
\text { (rpm) }\end{array}$ & $\mathrm{K}_{\mathrm{L}} \mathrm{a}\left(\mathrm{h}^{-1}\right)$ & Microorganisms & $\begin{array}{l}\text { Temperature } \\
\left({ }^{\circ} \mathrm{C}\right)\end{array}$ & Product & \begin{tabular}{|l} 
Productivity / \\
Titer
\end{tabular} & References \\
\hline CSTR & $\begin{array}{l}63.43 \% \mathrm{CO}, 15.96 \% \\
\mathrm{CO}_{2} \text { and } 20.61 \% \\
\mathrm{CH}_{4}\end{array}$ & 0.325 & NA* & 6.35 & 400 & $36.6 \mathrm{~h}$ & $\begin{array}{l}\text { Peptostreptococcus } \\
\text { productus }\end{array}$ & 37 & acetate & $\begin{array}{l}4.8 \\
\mathrm{mmol} \cdot \mathrm{L}_{\mathrm{RWV}}{ }^{-1} \cdot \mathrm{h}^{-1}\end{array}$ & [97] \\
\hline CSTR & \begin{tabular}{|l|} 
conventional \\
sparging $20 \% \mathrm{H}_{2}$, \\
$15 \% \mathrm{Ar}, 55 \% \mathrm{CO}$, \\
and $10 \% \mathrm{CO}_{2}$ \\
microbubble \\
sparging $20 \% \mathrm{H}_{2}$, \\
$15 \% \mathrm{Ar}, 55 \% \mathrm{CO}$, \\
and $10 \% \mathrm{CO}_{2}$ \\
\end{tabular} & 1.5 & NA & 300 & 200 & $90.64 \mathrm{~h}$ & $\begin{array}{l}\text { Butyribacterium } \\
\text { methylotrophicum }\end{array}$ & 37 & acetate & $\begin{array}{l}2.71 \\
\mathrm{mmol} \cdot \mathrm{L}_{\mathrm{RWV}}{ }^{-1} \cdot \mathrm{h}^{-1}\end{array}$ & [88] \\
\hline Bubble column & $\begin{array}{l}\text { CO at different } \\
\text { partial pressures }\end{array}$ & 0.2 & NA & 80 & NA & $72 \mathrm{~h}$ & $\begin{array}{l}\text { Eubacterium } \\
\text { limosum }\end{array}$ & 37 & acetate & $\begin{array}{l}3.65 \\
\mathrm{mmol} \cdot \mathrm{L}_{\mathrm{RWv}}{ }^{-1} \cdot \mathrm{h}^{-1}\end{array}$ & [75] \\
\hline $\begin{array}{l}\text { Two stage: } \\
\text { CSTR - CSTR }\end{array}$ & $\begin{array}{l}30 \% \mathrm{H}_{2}, 30 \% \mathrm{CO}_{2} \\
40 \% \mathrm{CO}\end{array}$ & 2 & NA & 100 & 100 & $\mathrm{NM}^{* *}$ & $\begin{array}{l}\text { Clostridium } \\
\text { ragsdalei }\end{array}$ & 37 & \begin{tabular}{|l}
$\begin{array}{l}\text { ethanol, } \\
\text { acetate }\end{array}$ \\
\end{tabular} & NM & [77] \\
\hline $\begin{array}{l}\text { Two stage: } \\
\text { CSTR - Bubble } \\
\text { Column }\end{array}$ & $\begin{array}{l}60 \% \mathrm{CO}, 35 \% \mathrm{H}_{2} \\
\text { and } 5 \% \mathrm{CO}_{2}\end{array}$ & $\begin{array}{l}\text { CSTR: } 1, \\
\text { Bubble } \\
\text { column: } \\
4\end{array}$ & NA & $\begin{array}{l}\text { CSTR: } 25 \\
\text { Bubble } \\
\text { Column: } \\
133\end{array}$ & $\begin{array}{l}\text { CSTR: } \\
200\end{array}$ & NM & $\begin{array}{l}\text { Clostridium } \\
\text { ljungdahlii }\end{array}$ & 35 & ethanol & $\begin{array}{l}8.04 \\
\mathrm{mmol} \cdot \mathrm{L}_{\mathrm{RWV}}{ }^{-1} \cdot \mathrm{h}^{-1}\end{array}$ & [91] \\
\hline CSTR & $\begin{array}{l}55 \% \mathrm{CO}_{1} 20 \% \mathrm{H}_{2} \\
10 \% \mathrm{CO}_{2} \text { and } 15 \% \\
\text { argon }\end{array}$ & 2 & NA & 14 & 500 & NM & $\begin{array}{l}\text { Clostridium } \\
\text { ljungdahlii }\end{array}$ & 37 & $\begin{array}{l}\text { ethanol, } \\
\text { acetate }\end{array}$ & $\begin{array}{l}1.7 \\
\mathrm{mmol} \cdot \mathrm{L}_{\mathrm{RWv}}{ }^{-1} \cdot \mathrm{h}^{-1} \\
\text { ethanol and } 1.1 \\
\mathrm{mmol} \cdot \mathrm{L}_{\mathrm{RWv}}{ }^{-1} \cdot \mathrm{h}^{-1} \\
\text { acetate } \\
\end{array}$ & [92] \\
\hline CSTR & $\begin{array}{l}\text { syngas consisted of } \\
70 \% \text { CO }\end{array}$ & 2 & NA & 14 & 550 & $135 \mathrm{~h}$ & $\begin{array}{l}\text { Clostridium } \\
\text { ljungdahlii }\end{array}$ & 37 & $\begin{array}{l}\text { ethanol } \\
\text { and } \\
\text { acetate }\end{array}$ & \begin{tabular}{|l|} 
total \\
concentration \\
$11 \mathrm{~g} \cdot \mathrm{L}^{-1}$ \\
\end{tabular} & [93] \\
\hline
\end{tabular}


ACCEPTED MANUSCRIPT

\begin{tabular}{|c|c|c|c|c|c|c|c|c|c|c|c|}
\hline $\begin{array}{l}\text { RPB-BR } \\
\text { Rotating } \\
\text { Packed Bed } \\
\text { Bioreactor }\end{array}$ & $\begin{array}{l}20 \% \mathrm{CO}, 5 \% \mathrm{H}_{2} \\
15 \% \mathrm{CO}_{2} \text {, and } 60 \% \\
\mathrm{~N}_{2}\end{array}$ & 1.5 & $\begin{array}{l}\text { AnoxKaldnesTM } \\
\text { K1 carriers }\end{array}$ & 300 & $\begin{array}{l}50 \\
\text { (rotation } \\
\text { of } \\
\text { packed } \\
\text { bed) }\end{array}$ & $\begin{array}{l}70(100 \\
\text { rpm } \\
\text { and } 1 \\
\text { vvm })\end{array}$ & $\begin{array}{l}\text { Clostridium } \\
\text { carboxidivorans P7 }\end{array}$ & 37 & ethanol & $\begin{array}{l}6.06 \\
\mathrm{mmol} \cdot \mathrm{L}_{\mathrm{RWv}}{ }^{-1} \cdot \mathrm{h}^{-1}\end{array}$ & [96] \\
\hline HFMBR & $\begin{array}{l}20 \% \mathrm{CO}, 5 \% \mathrm{H}_{2}, \\
15 \% \mathrm{CO} 2, \text { and } 60 \% \\
\mathrm{~N}_{2}\end{array}$ & 8 & $\begin{array}{l}\text { microporous } \\
\text { hydrophobic } \\
\text { polypropylene } \\
\text { hollow fibers }\end{array}$ & 300 & NA & $\begin{array}{l}1096.2 \\
h\end{array}$ & $\begin{array}{l}\text { Clostridium } \\
\text { carboxidivorans P7 }\end{array}$ & 37 & ethanol & $\begin{array}{l}3.12 \\
\mathrm{mmol} \cdot \mathrm{L}_{\mathrm{RWV}}{ }^{-1} \cdot \mathrm{h}^{-1}\end{array}$ & [94] \\
\hline $\begin{array}{l}\text { Monolithic } \\
\text { Biofilm reactor }\end{array}$ & $\begin{array}{l}20 \% \mathrm{CO}, 5 \% \mathrm{H}_{2} \\
15 \% \mathrm{CO}_{2} \text { and } 60 \% \\
\mathrm{~N}_{2}\end{array}$ & 8 & $\begin{array}{l}\text { cordierite } \\
\text { based } \\
\text { monolithic } \\
\text { cylinder }\end{array}$ & 300 & NA & $450 \mathrm{~h}$ & $\begin{array}{l}\text { Clostridium } \\
\text { carboxidivorans P7 }\end{array}$ & 37 & ethanol & $\begin{array}{l}2.13 \\
\mathrm{mmol} \cdot \mathrm{L}_{\mathrm{RWV}}{ }^{-1} \cdot \mathrm{h}^{-1}\end{array}$ & [95] \\
\hline Trickle bed & $\begin{array}{l}38 \% \mathrm{CO}, 28.5 \% \mathrm{CO}_{2} \\
28.5 \% \mathrm{H}_{2} \text { and } 5 \% \mathrm{~N}_{2}\end{array}$ & 0.5 & $\begin{array}{l}\text { 6-mm soda lime } \\
\text { glass beads }\end{array}$ & 4.6 & NA & NM & $\begin{array}{l}\text { Clostridium } \\
\text { ragsdalei }\end{array}$ & 37 & $\begin{array}{l}\text { ethanol, } \\
\text { acetate }\end{array}$ & $\begin{array}{l}5.7 \mathrm{~g} \cdot \mathrm{L}^{-1}, 12.3 \\
\mathrm{~g} \cdot \mathrm{L}^{-1} \\
\text { respectively }\end{array}$ & [98] \\
\hline $\begin{array}{l}\text { Continuous } \\
\text { gas fed }\end{array}$ & CO $100 \%$ & 1.2 & NA & NM & 250 & NM & $\begin{array}{l}\text { Clostridium } \\
\text { autoethanogenum }\end{array}$ & 30 & $\begin{array}{l}\text { ethanol, } \\
\text { acetate }\end{array}$ & $\begin{array}{l}0.91 \mathrm{~g} \cdot \mathrm{L}^{-1} \text { and } \\
0.92 \mathrm{~g} \cdot \mathrm{L}^{-1}\end{array}$ & [99] \\
\hline CSTR & $\begin{array}{l}20 \% \mathrm{CO}, 15 \% \mathrm{CO}_{2} \\
5 \% \mathrm{H}_{2} \text { and } 60 \% \mathrm{~N}_{2}\end{array}$ & 3 & $\mathrm{NA}$ & NM & 150 & NM & $\begin{array}{l}\text { Clostridium strain } \\
\text { P11 }\end{array}$ & 37 & ethanol & $\begin{array}{l}0.58 \\
\mathrm{mmol} \cdot \mathrm{L}_{\mathrm{RWv}}{ }^{-1} \cdot \mathrm{h}^{-1}\end{array}$ & {$[100]$} \\
\hline Trickle bed & $\begin{array}{l}38 \% \mathrm{CO}, 5 \% \mathrm{~N}_{2} \\
28.5 \% \mathrm{CO}_{2} \text { and } \\
28.5 \% \mathrm{H}_{2}\end{array}$ & 1 & $\begin{array}{l}6 \mathrm{~mm} \text { soda lime } \\
\text { glass beads }\end{array}$ & 18.9 & NA & NM & $\begin{array}{l}\text { Clostridium } \\
\text { ragsdalei }\end{array}$ & 37 & ethanol & $\begin{array}{l}3.43 \\
\mathrm{mmol} \cdot \mathrm{L}_{\mathrm{RWV}}{ }^{-1} \cdot \mathrm{h}^{-1}\end{array}$ & [101] \\
\hline
\end{tabular}

*NA - Not Applied **NM - Not Mentioned 


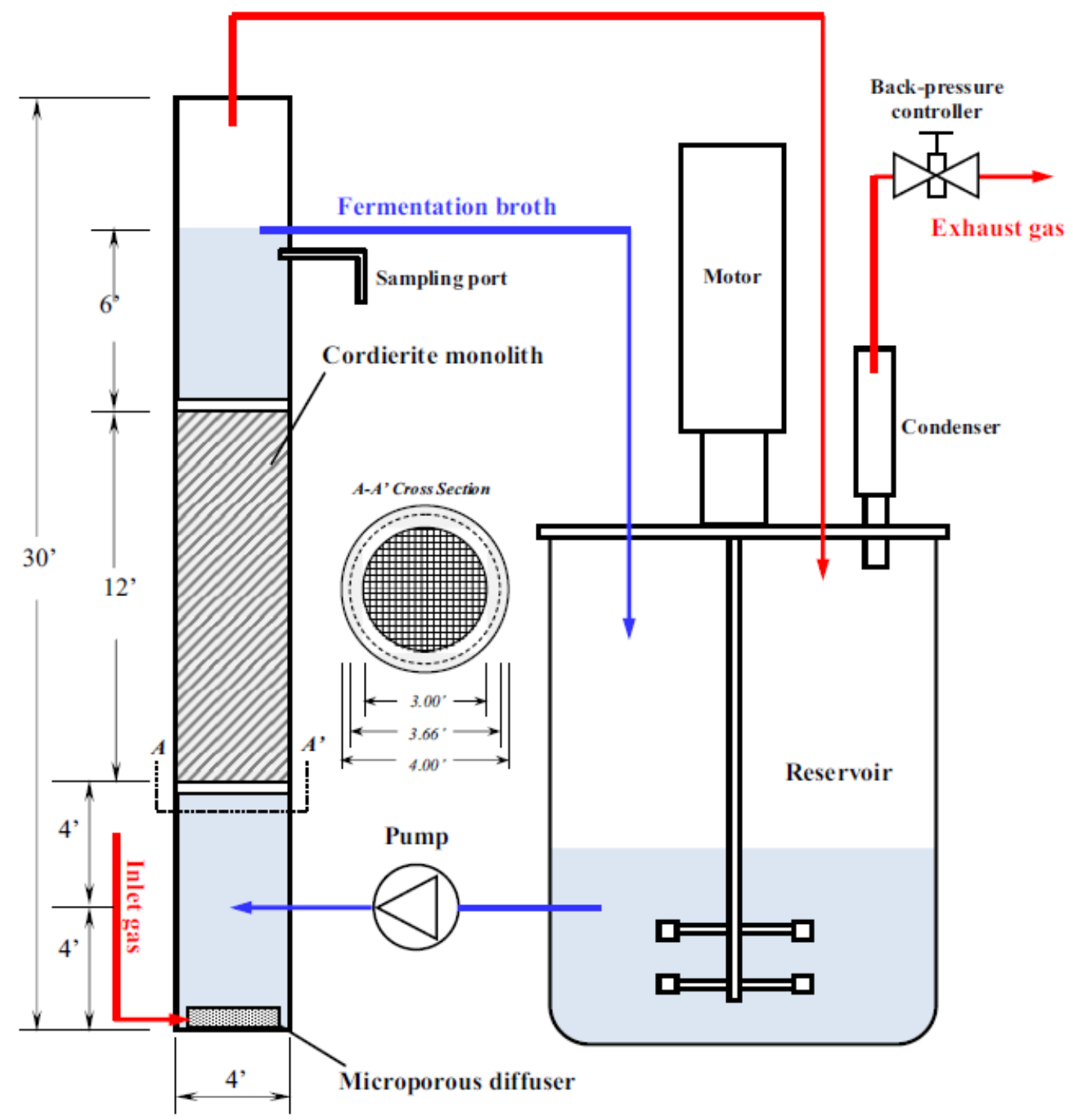

Figure 4. Schematics of the monolith biofilm reactor designed by Shen et al. [95]. The red lines depict the syngas flow and the blue lines the liquid flow. The liquid media flow in a loop from the agitated vessel to the bottom of the column, pass through the cordierite monolith (biofilm formed) where fermentation takes place and finally the fermentation broth flows back to the reservoir vessel from the top of the column. Syngas is inserted through a microporous diffuser in the bottom of the column and after its bioconversion in the biofilm it flows from the headspace of the column to the headspace of the reservoir agitated vessel.

Contrary to the current research status that opts for ethanol production Kantzow et al. [102] tried to maximize the acetate productivity taking advantage of the innate acetogenic nature of Acetobacterium woodii. For the experiments they used a CSTR reactor with a submerged hollow fiber membrane module to stimulate cell concentration. The membranes were constructed from hydrophilic polysulfone and they were used for full cell retention. It should be highlighted that $\mathrm{CO}$ was not included in the gas feed but a gas 
mixture of $\mathrm{H}_{2}, \mathrm{CO}_{2}$ and $\mathrm{N}_{2}$ was applied instead. The reactor was operated at $1200 \mathrm{rpm}$ stirring speed with a dilution rate of $0.35 \mathrm{~h}^{-1}$ and a productivity of $103.8 \mathrm{mmol} \cdot \mathrm{L}_{\mathrm{RWv}}{ }^{-1} \cdot \mathrm{h}^{-1}$ was achieved. This value was 7.1 times higher than the one without cell retention operated under the same conditions depicting the noteworthy contribution of the hollow fiber membrane module to gas fermentation.

Ethanol and acetate production from syngas has also been tested in trickle bed bioreactors. Devarapalli et al. harnessed the attribute of this configuration and filled a borosilicate glass column with $6 \mathrm{~mm}$ soda lime glass beads [98]. This bioreactor setup had already been proved to function for $\mathrm{CO}$ fermentation purposes [103]. After $1662 \mathrm{~h}$ of semi-continuous operation with biocatalyst Clostridium ragsdalei the concentrations of ethanol and acetate were 5.7 and $12.3 \mathrm{~g} \cdot \mathrm{L}^{-1}$ respectively when liquid recirculation rate was $400 \mathrm{~mL} \cdot \mathrm{min}^{-}$ ${ }^{1} \cdot \mathrm{L}_{\mathrm{RWv}}{ }^{-1}$, syngas flow $9.2 \mathrm{~mL} \cdot \mathrm{min}^{-1} \cdot \mathrm{L}_{\mathrm{RWv}}{ }^{-1}$, and the flow in co-current mode. Counter-current mode needs further optimization as the author reported flooding of the bed and foam formation at high liquid recirculation rates. The same researchers, studied the effects of dilution and gas flow rates on ethanol productivity by changing the setup from semi-continuous to continuous under co-current and countercurrent configurations [101]. They observed that ethanol productivity was higher during co-current mode with a maximum of $3.43 \mathrm{mmol} \cdot \mathrm{L}_{\mathrm{RWv}} \mathrm{v}^{-1} \cdot \mathrm{h}^{-1}$ at $0.012 \mathrm{~h}^{-1}$ dilution, gas flow $18.9 \mathrm{~mL} \cdot \mathrm{min}^{-1} \cdot \mathrm{L}_{\mathrm{RWv}}{ }^{-1}$ and liquid recirculation rate of $200 \mathrm{~mL} \cdot \mathrm{min}^{-1} \cdot \mathrm{L}_{\mathrm{RWV}}{ }^{-1}$. Flooding issues under counter-current mode were observed again resulting to over two times less ethanol production compared to co-current mode.

In an effort to diminish the cost of media broth, Maddipati et al. [100] replaced $1 \mathrm{~g} \cdot \mathrm{L}^{-1}$ yeast extract with the much cheaper $20 \mathrm{~g} \cdot \mathrm{L}^{-1}$ corn steep liquor (CSL) and run experiments in continuous mode in a chemostat. Clostridium strain $P 11$ was used as a biocatalyst and the agitation speed was relatively low at $150 \mathrm{rpm}$. Albeit higher ethanol concentration values were achieved with $20 \mathrm{~g} \cdot \mathrm{L}^{-1} \mathrm{CSL}$ in the medium, the productivity of ethanol was very low $\left(0.58 \mathrm{mmol} \cdot \mathrm{L}_{\mathrm{RWv}}{ }^{-1} \cdot \mathrm{h}^{-1}\right)$ due to the poor conversion efficiency of $\mathrm{CO}$ and $\mathrm{H}_{2}$. In another study the addition of $0.75 \mu \mathrm{m}$ tungsten to the media solution for continuous syngas fermentation with Clostridium autoethanogenum led to an interesting observation, that is at $\mathrm{pH} 4.75$ no accumulation of 
acetate took place [99]. The aforementioned bioreactor set-ups are summed up in table 2 where crucial information on operational parameters is also presented.

\subsection{Production of Long Chain Alcohols (Butanol - Hexanol)}

Butanol is a liquid fuel that can supplant the use of gasoline and it is emerging as a game-changer in the current view of biofuels [104-106]. Although studies about ethanol production from syngas fermentation can be ubiquitously found, there is limited information regarding continuous production of butanol with syngas compounds as a carbon and energy source. The main reason is that there are few acidogens discovered that can produce butanol naturally $[35,36]$ and therefore metabolic engineering approaches are needed for high butanol selectivity [107-109]. In addition to that, butanol has been reported to be inhibitory to carboxydotrophic clostridia [110] and mixed microbial consortia demand a high hydraulic retention times in order to implement carbon elongation [111].

Clostridium carboxidivorans is a microbe that has recently drawn a lot of attention in terms of its inherent ability to produce long chain alcohols [110,112-115]. A try for consolidated butanol - ethanol production was attempted with Clostridium carboxidivorans P7 in a CSTR reactor with agitation speed of $250 \mathrm{rpm}$ and temperature of $33^{\circ} \mathrm{C}[116]$. Two experiments were performed under the same conditions except for the pH control. In the first experiment pH was constant at 5.75 for $408 \mathrm{~h}$ and then its value was changed to 4.75 . The maximum ethanol and butanol concentrations achieved were $5.55 \mathrm{~g} \cdot \mathrm{L}^{-1}$ and $2.66 \mathrm{~g} \cdot \mathrm{L}^{-1}$ respectively. In the second experiment $\mathrm{pH}$ was gradually decreased from 5.75 to 4.75 after $72 \mathrm{~h}$ of operation and the maximum concentrations succeeded were $2.90 \mathrm{~g} \cdot \mathrm{L}^{-1}$ for ethanol and $1.60 \mathrm{~g} \cdot \mathrm{L}^{-1}$ for butanol. The reason for the lower concentrations in the second experiment was that biomass formation was not favored in low $\mathrm{pH}$. Clostridium carboxidivorans $\mathrm{P7}$ converts $\mathrm{CO}$ first to fatty acids at high $\mathrm{pH}$ (acidogenic phase combined with cell growth) and then the formed fatty acids are converted to alcohols at lower $\mathrm{pH}$.

In a syngas fermentation study with bacterium Alkalibaculum bacchi an unexpected production of butanol and propanol was observed [117]. The researchers performed 16S rRNA screening of the liquid medium 
looking for possible contaminations and the results showed the existence of Clostridium propionicum in the fermentation broth. Driven by the incentive to produce higher alcohols with the aforementioned co-culture they performed semi-continuous experiments in a CSTR reactor [118]. The concentrations of alcohols achieved were not high but the results were promising for further research in co-culture syngas fermentations for the production of higher alcohols. Richter et al. [119] deployed a CSTR reactor, inoculated with a co-culture of Clostridium ljungdahlii and Clostridium kluyveri, connected in line with downstream processing for the production of long chain alcohols from syngas. The reactor volume was $1 \mathrm{~L}$, agitated at $400 \mathrm{rpm}$, the temperature was at $37^{\circ} \mathrm{C}$ and the syngas fed in the reactor had a composition of $60 \% \mathrm{CO}(\mathrm{vol} / \mathrm{vol}), 35 \% \mathrm{H}_{2}$ and $5 \% \mathrm{CO}_{2}$. While the $\mathrm{pH}$ was controlled at 6 and the dilution rate was set at 40 $\mathrm{mL} \cdot \mathrm{h}^{-1}$ the net productivities of $\mathrm{n}$-butanol and $\mathrm{n}$-hexanol were $0.408 \mathrm{mmol} \cdot \mathrm{L}_{\mathrm{RWv}}{ }^{-1} \cdot \mathrm{h}^{-1}$ and $0.220 \mathrm{mmol} \cdot \mathrm{L}_{\mathrm{RWv}}{ }^{-}$ ${ }^{1} \cdot \mathrm{h}^{-1}$, respectively. It should be highlighted that under the same operational conditions traces of $\mathrm{n}$-octanol were reported at the condensate of the reactor. Another co-culture study was performed in anaerobic bottles by Diender et al. [120], who showed that $C$. autoethanogenum and C. kluyveri can work together and convert $\mathrm{CO}$ or syngas to medium chain fatty acids and their respective alcohols. The researchers proposed also a model for the metabolic interactions of the two microbes leading to the production of long chain alcohols.

\subsection{Methane Production}

The first efforts to ferment gas to $\mathrm{CH}_{4}$ in a continuous process are dated back to 1978 [121]. Wise et al. examined the efficiency of a CSTR reactor functioning under mesophilic and thermophilic conditions, inoculated with mixed microbial consortia from an anaerobic sludge digester. Mixed microbial consortia from anoxic environments are hosts to a vast variety of microorganisms including methanogenic archaea that can reduce $\mathrm{C} 1$ sources to $\mathrm{CH}_{4}$ [122]. Following the stoichiometry, that is for the production of $1 \mathrm{~mol}$ of $\mathrm{CH}_{4}, 4$ mol of $\mathrm{H}_{2}$ and $1 \mathrm{~mol}$ of $\mathrm{CO}_{2}$ are needed [123], the gas mixture used as a substrate was $\mathrm{H}_{2}$ and $\mathrm{CO}_{2}$ in a 4:1 ratio. A cell recycle system was also applied to increase cell concentration. At mesophilic conditions (37 ${ }^{\circ} \mathrm{C}$ ) and atmospheric pressure the maximum $\mathrm{CH}_{4}$ productivity achieved was $178.4 \mathrm{mmol} \cdot \mathrm{L}_{\mathrm{RWv}}{ }^{-1} \cdot \mathrm{h}^{-1}$ with the 
reactor operated at $3.5 \mathrm{~d}$ of liquid retention time. Another interesting outcome of this study was that although gas solubility decreases in elevated temperatures better $\mathrm{CH}_{4}$ productivity could be achieved (446 $\mathrm{mmol} \cdot \mathrm{L}_{\mathrm{RWv}}{ }^{-1} \cdot \mathrm{h}^{-1}$ at $2-2.5 \mathrm{~d}$ liquid retention time and $60^{\circ} \mathrm{C}$ ). According to a study for gas diffusivity in water, the diffusion rate of $\mathrm{CO}$ doubles from $35^{\circ} \mathrm{C}$ to $60{ }^{\circ} \mathrm{C}$ acting as an offset to the decreased solubility [124]. Introduction of $3 \% \mathrm{CO}$ to the gas feed resulted to a washing out of the cells at a liquid retention time of $8 \mathrm{~d}$ indicating the toxic effects of $\mathrm{CO}$.

$\mathrm{CH}_{4}$ production from syngas was attempted successfully with a triculture consisting of the photosynthetic bacterium $R$. rubrum and two methanogens, $M$. formicicum and $M$. barkeri $[125,126]$. The research group examined four bioreactor setups, three of which were trickle bed reactors and one a packed bubble column. In all cases the syngas composition was the same but the working volume of the reactors was different. The two trickle bed reactors with volumes as low as $0.736 \mathrm{~L}$ and $1.051 \mathrm{~L}$, packed with Intalox saddles presented the highest $\mathrm{CH}_{4}$ productivities of 3.4 and $3.3 \mathrm{mmol} \cdot \mathrm{L}_{\mathrm{RWv}}{ }^{-1} \cdot \mathrm{h}^{-1}$ respectively while a scaled up trickle bed reactor with a volume of $26 \mathrm{~L}$ exhibited an almost 10 fold decrease in maximum $\mathrm{CH}_{4}$ productivity. A point to be taken into account though, is that the packing material used in the scaled-up reactor was different. The maximum $\mathrm{CH}_{4}$ productivity of $0.4 \mathrm{mmol} \cdot \mathrm{L}_{\mathrm{Rwv}}{ }^{-1} \cdot \mathrm{h}^{-1}$ achieved with the packed bubble column bioreactor was significantly lower than the low volume trickle bed reactors indicating that the latter bioreactor configuration is more efficient. Burkhardt et al. [127] used a pilot scale trickle bed reactor $\left(61 \mathrm{~L}\right.$ ) to convert $\mathrm{H}_{2}$ and $\mathrm{CO}_{2}$ to $\mathrm{CH}_{4}$ and achieved a high product quality (gas of $98 \% \mathrm{CH}_{4}$ ) with a productivity of $2.77 \mathrm{mmol} \cdot \mathrm{L}_{R \mathrm{WV}}{ }^{-1} \cdot \mathrm{h}^{-1}$ when the retention time of the gaseous substrate in the packed bed was $4 \mathrm{~h}$.

On the other hand Guiot et al. assessed the potential of microbial populations derived from an industrial granular sludge to convert $\mathrm{CO}$ to $\mathrm{CH}_{4}$ [128]. For their experiments they used a $30 \mathrm{~L}$ gas-lift reactor under mesophilic conditions $\left(30^{\circ} \mathrm{C}\right.$ ) and $\mathrm{N}_{2}-\mathrm{CO}$ diluted gas inflow. The maximal $\mathrm{CH}_{4}$ specific productivity 
achieved was $0.126 \mathrm{mmol} \cdot \mathrm{gvss}^{-1} \cdot \mathrm{h}^{-1}$, when the gas recirculation rate was $600 \mathrm{~mL} \cdot \mathrm{min}^{-1}$ and gas retention time $8.6 \mathrm{~d}$, with the yield of $\mathrm{CH}_{4}$ from $\mathrm{CO}$ reaching $95 \%$ of the theoretical.

A similar idea deploying sewage sludge for simultaneous anaerobic digestion and CO biomethanation was developed by Luo et al. [129]. CO was fed to a stirred tank bioreactor through a hollow fiber membrane module while agitation at $150 \mathrm{rpm}$ was also applied. The $400 \mathrm{~mL}$ working volume fermentor, operated under thermophilic conditions $\left(55^{\circ} \mathrm{C}\right)$ and neutral $\mathrm{pH}$, presented a high $\mathrm{CH}_{4}$ productivity of $3.7 \mathrm{mmol} \cdot \mathrm{L}_{\mathrm{RWv}}{ }^{-}$ ${ }^{1} \cdot \mathrm{h}^{-1}$. However, the percentage of $\mathrm{CH}_{4}$ in the gas effluent was only $19.2 \%$ because of the high $\mathrm{CO}$ flow rate of $6.6 \mathrm{~mL} \cdot \mathrm{min}^{-1} \cdot \mathrm{L}_{\mathrm{RWV}}{ }^{-1}$ and, consequently, the low gas retention time of $2.5 \mathrm{~h}$. The CO fraction in the biogas effluent was $35.2 \%$. Sequencing tests showed that the main species involved in CO bioconversion were species close to Methanosarcina barkeri and Methanothermobacter thermautotrophicus. Detailed information on more operational parameters is presented in Table 3.

A reverse membrane bioreactor configuration was employed by Westman et al. [130] opting for full cell retention within the fermentation vessel. Flat plain hydrophilic PVDF membranes were used for the cell encasement, permeable for the substrate and the product but impermeable for the cells. The sachets containing the inoculum (anaerobic culture from municipal solid sludge digester) were heat-sealed and subsequently inserted in the liquid media. The bioreactor was operated under thermophilic conditions (55 $\left.{ }^{\circ} \mathrm{C}\right)$ with a syngas feed of $\mathrm{CO}(55 \% \mathrm{~mol}), \mathrm{H}_{2}(20 \% \mathrm{~mol})$, and $\mathrm{CO}_{2}(10 \% \mathrm{~mol})$ resulting to a maximum $\mathrm{CH}_{4}$ productivity of $0.35 \mathrm{mmol} \cdot \mathrm{L}_{\mathrm{RWV}}{ }^{-1} \cdot \mathrm{h}^{-1}$.

\subsection{Biodiesel Production}

Despite the broad range of bioreactor configurations proposed for syngas bioconversion, there is only one publication connecting syngas fermentation with continuous biodiesel production [131]. Hu et al. developed an integrated process for the conversion of syngas to lipids in two stages, a bubble column and a stirred tank reactor, linked in series. In the first stage the thermophilic anaerobic acetogen Moorella 
Table 3. Bioreactor configurations for methane production

\begin{tabular}{|c|c|c|c|c|c|c|c|c|}
\hline $\begin{array}{l}\text { Reactor } \\
\text { Configuration }\end{array}$ & Gas Composition & \begin{tabular}{|l} 
Working \\
Volume (L)
\end{tabular} & \begin{tabular}{|l|} 
Packing or \\
Hollow Fiber \\
Material \\
\end{tabular} & $\begin{array}{l}\text { Gas } \\
\text { Retention(h) }\end{array}$ & Microorganisms & Temperature $\left({ }^{\circ} \mathrm{C}\right)$ & 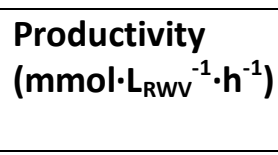 & References \\
\hline CSTR & $\mathrm{H}_{2}: \mathrm{CO}_{2}=4: 1$ & 2 & NA & NM & $\begin{array}{l}\text { mixed microbial } \\
\text { consortia from } \\
\text { anaerobic } \\
\text { sewage digester } \\
\text { (mesophilic) }\end{array}$ & 37 & 178.4 & [121] \\
\hline CSTR & $\mathrm{H}_{2}: \mathrm{CO}_{2}=4: 1$ & 1 & $N A$ & NM & $\begin{array}{l}\text { mixed microbial } \\
\text { consortia from } \\
\text { anaerobic } \\
\text { sewage digester } \\
\text { (thermophilic) }\end{array}$ & 60 & 446 & [121] \\
\hline Trickle bed & $\mathrm{H}_{2}: \mathrm{CO}_{2}=4: 1$ & 61 & \begin{tabular}{|l} 
Bioflow 40 \\
(RAUSCHERT)
\end{tabular} & 4 & $\begin{array}{l}\text { Anaerobic } \\
\text { sludge from } \\
\text { sewage plant }\end{array}$ & 37 & 2.77 & [127] \\
\hline Gas-lift & $\mathrm{CO}$ & 30 & NA & NM & $\begin{array}{l}\text { industrial } \\
\text { granular sludge }\end{array}$ & 37 & $0.126^{a}$ & [128] \\
\hline $\begin{array}{l}\text { Reverse membrane } \\
\text { bioreactor }\end{array}$ & $\begin{array}{l}55 \% \mathrm{CO}, 20 \% \mathrm{H}_{2} \\
\text { and } 10 \% \mathrm{CO}_{2}\end{array}$ & 0.6 & $\begin{array}{l}\text { Flat plain } \\
\text { hydrophilic } \\
\text { PVDF }\end{array}$ & NM & $\begin{array}{l}\text { anaerobic } \\
\text { culture from } \\
\text { municipal solid } \\
\text { sludge digester }\end{array}$ & 55 & 0.35 & [130] \\
\hline Trickle bed & $\begin{array}{l}14.8 \% \mathrm{Ar}, 9.9 \% \\
\mathrm{CO}_{2}, 55.6 \% \mathrm{CO} \text { and } \\
20.4 \% \mathrm{H}_{2}\end{array}$ & 0.736 & $\begin{array}{l}6.35 \mathrm{~mm} \\
\text { Intalox saddles }\end{array}$ & 2.45 & $\begin{array}{l}\text { triculture }(R . \\
\text { rubrum, } M . \\
\text { formicicum, } M . \\
\text { barkeri) }\end{array}$ & 37 & 3.4 & [125] \\
\hline $\begin{array}{l}\text { Packed bubble } \\
\text { column }\end{array}$ & $\begin{array}{l}15 \% \mathrm{Ar}, 9.6 \% \mathrm{CO}_{2}, \\
55 \% \mathrm{CO} \text { and } 20.4 \% \\
\mathrm{H}_{2}\end{array}$ & 3.26 & $\begin{array}{l}\text { Glass Raschig } \\
\text { rings (6 } \mathrm{mm} \times 6 \\
\mathrm{~mm} \text { ) }\end{array}$ & 3.40 & $\begin{array}{l}\text { triculture }(R . \\
\text { rubrum, } M . \\
\text { formicicum, } M . \\
\text { barkeri) }\end{array}$ & 34 & 0.4 & [125] \\
\hline Trickle bed & $\begin{array}{l}14.74 \% \mathrm{Ar}, 9.72 \% \\
\mathrm{CO}_{2}, 54.42 \% \mathrm{CO} \\
\end{array}$ & $\begin{array}{r}26.052 \\
\square\end{array}$ & Pall rings & 13 & $\begin{array}{l}\text { triculture }(R . \\
\text { rubrum, } M .\end{array}$ & 37 & 0.45 & [126] \\
\hline
\end{tabular}


ACCEPTED MANUSCRIPT

\begin{tabular}{|c|c|c|c|c|c|c|c|c|}
\hline & and $21.11 \% \mathrm{H}_{2}$ & & & & $\begin{array}{l}\text { formicicum, } M . \\
\text { barkeri) }\end{array}$ & & & \\
\hline Trickle bed & $\begin{array}{l}14.82 \% \mathrm{Ar}, 9.67 \% \\
\mathrm{CO}_{2}, 55.62 \% \mathrm{CO} \\
\text { and } 19.68 \% \mathrm{H}_{2}\end{array}$ & 1.051 & Intalox saddles & 1.05 & $\begin{array}{l}\text { triculture ( } R \text {. } \\
\text { rubrum, } M . \\
\text { formicicum, } M . \\
\text { barkeri) }\end{array}$ & 37 & 3.3 & {$[126]$} \\
\hline $\begin{array}{l}\text { CSTR with } \\
\text { submerged HFM }\end{array}$ & CO $100 \%$ & 0.4 & $\begin{array}{l}\text { Bundle of } 600 \\
\text { microporous } \\
\text { polypropylene } \\
\text { HFMs with } 40 \% \\
\text { porosity and } \\
0.04 \text { um pore } \\
\text { size } \\
\text { (Membrana) }\end{array}$ & 2.53 & $\begin{array}{l}\text { digested } \\
\text { sewage sludge }\end{array}$ & 55 & 2.54 & [129] \\
\hline
\end{tabular}

NA - Not Applied **NM - Not Mentioned

a: $\mathrm{mmol} \cdot \mathrm{gvss}^{-1} \cdot \mathrm{h}^{-1}$ 
thermoacetica fixed $\mathrm{CO}_{2}$ to acetate. The produced acetate acid was in turn pumped through a hollow membrane filter into an aerobic bioreactor, where it was used as a substrate by the genetically engineered oleaginous yeast, Yarrowia lipolytica, for the production of lipids. The overall productivity achieved with the two-stage lab scale system was $0.19 \mathrm{~g} \cdot \mathrm{L}_{\mathrm{RWv}}{ }^{-1} \cdot \mathrm{h}^{-1}[131]$. The same researchers' team had managed to produce acetate at a titer of $31 \mathrm{~g} \cdot \mathrm{L}^{-1}$ and a productivity of $9.16 \mathrm{mmol} \cdot \mathrm{L}_{\mathrm{RWv}}{ }^{-1} \cdot \mathrm{h}^{-1}$ under thermophilic conditions in a bubble column fermentor [132].

\subsection{Hydrogen Production}

The biological production of $\mathrm{H}_{2}$ from syngas has drawn less attention than other biofuels due to storage and delivery challenges [133]. In addition to that, syngas compared to other feedstocks presents high microbial toxicity due to its content in $\mathrm{CO}$, which results in diminished productivities. The microbes and the mechanisms involved in biological $\mathrm{H}_{2}$ production from $\mathrm{CO}$ have been recently reviewed in depth from Rittman et al. [134]. In short, carboxydotrophic hydrogenogens under strict anaerobic conditions convert $\mathrm{CO}$ and $\mathrm{H}_{2} \mathrm{O}$ to $\mathrm{H}_{2}$ and $\mathrm{CO}_{2}$ via the biological water-gas shift reaction.

Younesi et al. [135] used a CSTR configuration to produce $\mathrm{H}_{2}$ from syngas with photosynthetic bacterium Rhodospirillum rubrum as a biocatalyst. At an optimized syngas flow rate of $14 \mathrm{~mL} \cdot \mathrm{min}^{-1}$ and an agitation speed of $500 \mathrm{rpm}$ the maximum $\mathrm{H}_{2}$ productivity achieved was $24 \mathrm{mmol} \cdot \mathrm{L}_{\mathrm{RWv}}{ }^{-1} \cdot \mathrm{h}^{-1}$ which was higher than the one reported by Klasson et al. $\left(4.7 \mathrm{mmol} \cdot \mathrm{L}_{\mathrm{RWv}}{ }^{-1} \cdot \mathrm{h}^{-1}\right)$ using the same bacterium and the same syngas composition $\left(20 \% \mathrm{H}_{2}, 15 \% \mathrm{Ar}, 55 \% \mathrm{CO}\right.$ and $\left.10 \% \mathrm{CO}_{2}\right)$, but different source of carbon for cell growth. [136]. An increased productivity of $\mathrm{H}_{2}$ from $\mathrm{CO}$ was achieved in a HFMBR with a pure culture of the extremely thermophilic bacterium Carboxydothermus hydrogenoformans [137]. Evaluation of a combination of several different operational conditions led to the observation that maximum CO conversion occurs at 70 ${ }^{\circ} \mathrm{C}$, with a CO partial pressure of $2 \mathrm{~atm}$ and liquid velocity through the hollow fiber membrane module of $130 \mathrm{~m} \cdot \mathrm{h}^{-1}$, resulting to a $\mathrm{H}_{2}$ productivity of $125 \mathrm{mmol} \cdot \mathrm{L}_{\mathrm{RWv}}{ }^{-1} \cdot \mathrm{h}^{-1}$. The same microorganism was also tested for its CO conversion bioactivity in a $30 \mathrm{~L}$ gas-lift reactor[138]. Due to a low biomass concentration (highest 
value achieved was $0.106 \mathrm{gvss}_{\mathrm{vs}} \cdot \mathrm{LRwV}^{-1}$ ) the maximum $\mathrm{H}_{2}$ productivity was $6.7 \mathrm{mmol} \cdot \mathrm{L}_{\mathrm{RWv}}{ }^{-1} \cdot \mathrm{h}^{-1}$, which is a value 18 times lower than the one with the HFMBR module.

A different strategy was followed from Oh et al. [139] who cultivated Rhodopseudomonas palustris P4 in a CSTR (5 L working volume) system under aerobic conditions with sucrose as a substrate before switching to anaerobic conditions with $10 \% \mathrm{CO}$ in the gas phase. The $\mathrm{pH}$ was maintained at 7 , the temperature at $30{ }^{\circ} \mathrm{C}$ and the agitation at $700 \mathrm{rpm}$. When the gas retention time was at $5 \mathrm{~min}$ and the inlet $\mathrm{CO}$ fraction $20 \%$, the maximum $\mathrm{H}_{2}$ productivity was $41 \mathrm{mmol} \cdot \mathrm{L}_{\mathrm{RWV}}{ }^{-1} \cdot \mathrm{h}^{-1}$ with a $61 \% \mathrm{CO}$ conversion efficiency. The same concept of aerobic growth with sucrose before the initiation of anaerobic CO fermentation was conducted in a CSTR reactor ( 3 L working volume) by Jung et al. [140] with Citobacter sp. Y19. The temperature was maintained at $30{ }^{\circ} \mathrm{C}$, the $\mathrm{pH}$ at 7 and the agitation at $500 \mathrm{rpm}$ with a $\mathrm{H}_{2}$ productivity estimated at $5.71 \mathrm{mmol} \cdot \mathrm{L}_{\mathrm{RWv}}{ }^{-1} \cdot \mathrm{h}^{-1}$.

Kim et al. [141] studied the effectiveness of a genetically engineered Thermococcus onnurineus NA1 strain to convert a $100 \% \mathrm{CO}$ gas phase into $\mathrm{H}_{2}$ and compared it to the wild type strain. For their experiments they used a CSTR reactor ( $2 \mathrm{~L}$ working volume) at $80^{\circ} \mathrm{C}$, with the $\mathrm{pH}$ controlled at $6.1-6.2$ and the agitation speed set at $300 \mathrm{rpm}$. When CO was continuously fed with a flow rate of $240 \mathrm{~mL} \mathrm{~min}^{-1}$, the $\mathrm{H}_{2}$ productivity achieved was $123.5 \mathrm{mmol} \cdot \mathrm{L}_{\mathrm{RWv}}{ }^{-1} \cdot \mathrm{h}^{-1}$, whereas for the wild type strain was $31.8 \mathrm{mmol} \cdot \mathrm{L}_{\mathrm{RWv}}{ }^{-1} \cdot \mathrm{h}^{-1}$. The aforementioned continuous experiments are collected in Table 4 
Table 4. Bioreactor configurations for hydrogen production

\begin{tabular}{|c|c|c|c|c|c|c|c|}
\hline $\begin{array}{l}\text { Reactor } \\
\text { Configuration }\end{array}$ & Gas Composition & $\begin{array}{l}\text { Working } \\
\text { Volume (L) }\end{array}$ & $\begin{array}{l}\text { Gas Retention } \\
\text { (h) }\end{array}$ & Microorganisms & Temperature $\left({ }^{\circ} \mathrm{C}\right)$ & $\begin{array}{l}\text { Productivity } \\
\left(\mathrm{mmol}^{\prime} \mathrm{L}_{\mathrm{RWv}}{ }^{-1} \cdot \mathrm{h}^{-1}\right)\end{array}$ & References \\
\hline CSTR & $\begin{array}{l}\mathrm{H} 2, \mathrm{Ar}, \mathrm{CO}, \text { and CO2 } \\
(20 / 15 / 55 / 10)\end{array}$ & 2 & 2.4 & $\begin{array}{l}\text { Rhodospirillum } \\
\text { rubrum }\end{array}$ & 30 & 24 & {$[135]$} \\
\hline CSTR & $\begin{array}{l}\mathrm{H} 2, \mathrm{Ar}, \mathrm{CO}, \text { and } \mathrm{CO} 2 \\
(20 / 15 / 55 / 10)\end{array}$ & 1.25 & NM & $\begin{array}{l}\text { Rhodospirillum } \\
\text { rubrum }\end{array}$ & 30 & 4.7 & [136] \\
\hline HFMBR & $\mathrm{CO}$ & 0.16 & NM & $\begin{array}{l}\text { Carboxydothermus } \\
\text { hydrogenoformans }\end{array}$ & 70 & 125 & [137] \\
\hline Gas-Lift & $\mathrm{CO}$ & 30 & NM & $\begin{array}{l}\text { Carboxydothermus } \\
\text { hydrogenoformans }\end{array}$ & 70 & 6.7 & [138] \\
\hline CSTR & N2 and $\mathrm{CO}(80 / 20)$ & 5 & 0.08 & $\begin{array}{l}\text { Rhodopseudomonas } \\
\text { palustris } P 4\end{array}$ & 30 & 41 & [139] \\
\hline CSTR & N2 and CO (90/10) & 3 & 0.25 & Citobacter sp. Y19 & 30 & 5.71 & {$[140]$} \\
\hline CSTR & $\mathrm{CO}$ & 2 & 0.14 & $\begin{array}{l}\text { genetically engineered } \\
\text { Thermococcus } \\
\text { onnurineus NA1 }\end{array}$ & 80 & 123.5 & {$[141]$} \\
\hline
\end{tabular}




\section{Commercialization of syngas fermentation}

Ineos Bio is a company established in 2008 but its bioethanol project started from 2001[142]. A great deal of research including pilot scale tests (where gasification, fermentation and distillation were integrated) led to the industrialization of the process in late 2012 with a capacity of 8 MMGY (million gallons per year) ethanol and $6 \mathrm{MW}$ electricity [143]. The company deployed proprietary naturally occurring biocatalysts with high selectivity to ethanol and tolerant to most impurities produced in the gasification process [142]. The ethanol produced had $99.7 \%$ purity so that it could be mixed with gasoline. However, the plant was idled in 2015 and on September 2016 the company announced its intention to sell the ethanol business due to changes in the US ethanol market that did not conform to their strategic objectives [143]. On July 2017 Alliance Bio-Products Inc. gained the approval of USDA (United States Department of Agriculture) to purchase the Ineos Bio plant with the company planning to use the facility to enhance their cellulose-tosugar process [144].

Lanzatech is close to commercializing a process converting steel mill off gases to ethanol with two plants being currently under construction; one in China with an ethanol capacity of 16 MMGY and one in Belgium with 21 MMGY [145]. The company uses a proprietary microbial strain for the bioconversion of synthesis gas and a hybrid separation system with water recycle for the purification of the product and the collection of the co-products. The process is already tested in their pre-commercial scale plant in China. Lanzatech presents a high activity, with more than 40 international partnerships with the academia and the private sector, targeting the development of platforms that will convert syngas to a bigger variety of products such as jet fuel, butadiene, 2,3-butanediol, isopropanol and isobutylene [145].

Another company doing business with syngas fermentation was Coskata that developed a semi-commercial process for the fermentation of syngas to fuel chemicals. However, the company went out of business in 2015 and its technology was acquired by the company Synata Bio [146]. 


\section{Conclusions and future perspectives}

The evolution of syngas fermentation platforms has an orientation towards packed bed bioreactors and membrane modules combined with biofilm formation. The main reason for the thriving research effort in biofilm reactors is the increased mass transfer that they can provide compared to the traditional bubble column and CSTR systems as well as the enhanced cell retention within the reactor. Recent literature findings show promising ethanol productivities with a rotating packed bed bioreactor and a trickle bed bioreactor configuration while new metabolic engineering techniques have been mainly applied towards an efficient production of higher alcohols and hydrogen. Novel ideas such as reverse membrane bioreactors and hollow fiber membrane bioreactors spring up for syngas biomethanation, yet, more experimental experience is required for the industrial success of these types of set-ups. Future research on the development of bioreactor configurations for continuous syngas fermentation should focus on the 1) design of novel modules that would further enhance gas-to-liquid mass transfer, 2) optimization of the operational parameters in the already used and studied set-ups, 3) combinations of bioreactors in series, 4) study of the versatility of a bioreactor for the production of different bioproducts, the economic assessment and the scale-up potential of the proposed platforms.

\section{Acknowledgements}

This work was financially supported by the Technical University of Denmark (DTU) and Innovation Fund Denmark in the frame of SYNFERON project.

\section{References}

[1] P. Roy, A. Dutta, B. Deen, Greenhouse gas emissions and production cost of ethanol produced from biosyngas fermentation process, Bioresour. Technol. 192 (2015) 185-191. doi:10.1016/j.biortech.2015.05.056. 
[2] B. Li, T. Gasser, P. Ciais, B. Yves, D. Hauglustaine, J.-P. Boisier, Z. Chen, M. Huang, L. Li, Y. Li, H. Liu, J. Liu, S. Peng, S. Piao, Z. Shen, Z. Sun, R. Wang, T. Wang, Y. Yin, H. Zeng, Z. Zeng, F. Zhou, S. Tao, The contribution of China's emissions to global climate forcing, Nature. 531 (2016) 357-361. doi:10.1038/nature17165.

[3] M. Christophe, P. Ekins, The geographical distribution of fossil fuels unused when limiting global warming to 2 oC, Nature. 517 (2015) 187-190. doi:10.1038/nature14016.

[4] J. Hansen, P. Kharecha, M. Sato, Climate forcing growth rates: doubling down on our Faustian bargain, Env. Res Lett. 8 (2013) 11006. doi:10.1088/1748-9326/8/1/011006.

[5] P. Friedlingstein, R.M. Andrew, J. Rogelj, G.P. Peters, J.G. Canadell, R. Knutti, G. Luderer, M.R. Raupach, M. Schaeffer, D.P. van Vuuren, L.C. Quéré, Persistent growth of CO2 emissions and implications for reaching climate targets, Nat Geosci. 7 (2014) ngeo2248. doi:10.1038/ngeo2248.

[6] M. Mohammadi, G.D. Najafpour, H. Younesi, P. Lahijani, M. Uzir, A. Mohamed, Bioconversion of synthesis gas to second generation biofuels: A review, Renew Sustain Energy Rev. 15 (2011) 42554273. doi:10.1016/j.rser.2011.07.124.

[7] V.G. Debabov, Bioethanol from synthesis gas, Appl Biochem Micro+. 49 (2013) 619-628. doi:10.1134/S000368381307003X.

[8] A. Grimalt-Alemany, I. V Skiadas, H.N. Gavala, Syngas biomethanation: state-of-the-art review and perspectives, Biofuels, Bioprod. Biorefining. 12 (2018) 139-158. doi:10.1002/bbb.1826.

[9] S. Redl, M. Diender, T. Jensen, D.Z. Sousa, A. Nielsen, Exploiting the potential of gas fermentation, Ind Crop Prod. 106 (2017) 21-30. doi:10.1016/j.indcrop.2016.11.015.

[10] J.R. Phillips, R.L. Huhnke, H.K. Atiyeh, Syngas Fermentation: A Microbial Conversion Process of Gaseous Substrates to Various Products, Ferment. 3 (2017) 28. doi:10.3390/fermentation3020028. 
[11] S. Wainaina, I. Horváth, M.J. Taherzadeh, Biochemicals from food waste and recalcitrant biomass via syngas fermentation: A review, Bioresour. Technol. (2017). doi:10.1016/j.biortech.2017.06.075.

[12] F. Liew, M.E. Martin, R.C. Tappel, B.D. Heijstra, C. Mihalcea, M. Köpke, Gas Fermentation-A Flexible Platform for Commercial Scale Production of Low-Carbon-Fuels and Chemicals from Waste and Renewable Feedstocks, Front. Microbiol. 7 (2016) 694. doi:10.3389/fmicb.2016.00694.

[13] B. Molitor, H. Richter, M.E. Martin, R.O. Jensen, A. Juminaga, C. Mihalcea, L.T. Angenent, Carbon recovery by fermentation of CO-rich off gases - Turning steel mills into biorefineries, Bioresour. Technol. 215 (2016) 386-396. doi:10.1016/j.biortech.2016.03.094.

[14] H. Latif, A.A. Zeidan, A.T. Nielsen, K. Zengler, Trash to treasure: Production of biofuels and commodity chemicals via syngas fermenting microorganisms, Curr. Opin. Biotechnol. 27 (2014) 7987. doi:10.1016/j.copbio.2013.12.001.

[15] B. Acharya, P. Roy, A. Dutta, Review of syngas fermentation processes for bioethanol, Biofuels. 5 (2015) 551-564. doi:10.1080/17597269.2014.1002996.

[16] P. Munasinghe, S. Khanal, Biomass-derived syngas fermentation into biofuels: Opportunities and challenges, Bioresour. Technol. 101 (2010) 5013-5022. doi:10.1016/j.biortech.2009.12.098.

[17] J. Daniell, M. Kopke, S.D. Simpson, Commercial biomass syngas fermentation, Energies. 5 (2012) 5372-5417. doi:10.3390/en5125372.

[18] A. Molino, S. Chianese, D. Musmarra, Biomass gasification technology: The state of the art overview, J Energy Chem. 25 (2016) 10-25. doi:10.1016/j.jechem.2015.11.005.

[19] J. Kopyscinski, T.J. Schildhauer, S. Biollaz, Production of synthetic natural gas (SNG) from coal and dry biomass - A technology review from 1950 to 2009, Fuel. 89 (2010) 1763-1783. doi:10.1016/j.fuel.2010.01.027. 
[20] S. Heidenreich, P.U. Foscolo, New concepts in biomass gasification, Prog. Energy Combust. Sci. 46 (2015) 72-95. doi:https://doi.org/10.1016/j.pecs.2014.06.002.

[21] Y.H. Li, Z. Chen, P. Watkinson, X. Bi, J. Grace, C.J. Lim, N. Ellis, A novel dual-bed for steam gasification of biomass, Biomass Convers. Biorefinery. (2017). doi:10.1007/s13399-017-0288-0.

[22] R. Andrew, D.T. Gokak, P. Sharma, S. Gupta, Novel hydrogen-rich gas production by steam gasification of biomass in a research-scale rotary tubular helical coil gasifier, Int. J. Energy Res. 40 (2016) 1788-1799. doi:10.1002/er.3558.

[23] G. Lopez, M. Artetxe, M. Amutio, J. Alvarez, J. Bilbao, M. Olazar, Recent advances in the gasification of waste plastics. A critical overview, Renew Sustain Energy Rev. 82 (2018) 576-596. doi:10.1016/j.rser.2017.09.032.

[24] A Roadmap for moving to a competitive low carbon economy in 2050, European Commission, Brussels, 2011. http://eur-lex.europa.eu/legal-content/EN/ALL/?uri=CELEX:52011DC0112.

[25] P. Dürre, B.J. Eikmanns, C1-carbon sources for chemical and fuel production by microbial gas fermentation, Curr. Opin. Biotechnol. 35 (2015) 63-72. doi:10.1016/j.copbio.2015.03.008.

[26] D.W. Griffin, M.A. Schultz, Fuel and chemical products from biomass syngas: A comparison of gas fermentation to thermochemical conversion routes, Env. Prog Sustain Energy. 31 (2012) 219-224. doi:10.1002/ep.11613.

[27] R.M. Slivka, M.S. Chinn, A.M. Grunden, Gasification and synthesis gas fermentation : an alternative route to biofuel production Gasification and synthesis gas fermentation : an alternative route to biofuel production, Biofuels. 2 (2011) 405-419. doi:10.4155/bfs.11.108.

[28] H.N. Abubackar, M.C. Veiga, C. Kennes, Biological conversion of carbon monoxide: Rich syngas or waste gases to bioethanol, Biofuels, Bioprod. Biorefining. 5 (2011) 93-114. doi:10.1002/bbb.256. 
[29] K.T. Klasson, M.D. Ackerson, E.C. Clausen, J.L. Gaddy, Bioreactors for synthesis gas fermentations, Resour. Conserv. Recycl. 5 (1991) 145-165. doi:10.1016/0921-3449(91)90022-G.

[30] M.D. Bredwell, P. Srivastava, R.M. Worden, Reactor design issues for synthesis-gas fermentations, Biotechnol. Prog. 15 (1999) 834-844. doi:10.1021/bp990108m.

[31] S.K. Khanal, Anaerobic Reactor Configurations for Bioenergy Production, in: S.K. Khanal (Ed.), Anaerob. Biotechnol. Bioenergy Prod., Wiley-Blackwell, Oxford, UK, 2009: pp. 93-114. doi:10.1002/9780813804545.ch5.

[32] C. Perego, D. Bianchi, Biomass upgrading through acid-base catalysis, Chem. Eng. J. 161 (2010) 314322. doi:https://doi.org/10.1016/j.cej.2010.01.036.

[33] P. Alvira, E. Tomás-Pejó, M. Ballesteros, M.J. Negro, Pretreatment technologies for an efficient bioethanol production process based on enzymatic hydrolysis: A review, Bioresour. Technol. 101 (2010) 4851-4861. doi:https://doi.org/10.1016/j.biortech.2009.11.093.

[34] D. Kennes, H.N. Abubackar, M. Diaz, M.C. Veiga, C. Kennes, Bioethanol production from biomass: Carbohydrate vs syngas fermentation, J. Chem. Technol. Biotechnol. 91 (2016) 304-317. doi:10.1002/jctb.4842.

[35] F. Ánxela, M.C. Veiga, C. Kennes, H-B-E (hexanol-butanol-ethanol) fermentation for the production of higher alcohols from syngas/waste gas, J Chem Technol Biot. 92 (2017) 712-731. doi:10.1002/jctb.5194.

[36] P. Dürre, Butanol formation from gaseous substrates, Fems Microbiol Lett. 363 (2016) fnw040. doi:10.1093/femsle/fnw040.

[37] H. Luk, C. Mondelli, D. Ferré, J.A. Stewart, P.-R. Javier, Status and prospects in higher alcohols synthesis from syngas, Chem Soc Rev. 46 (2016) 1358-1426. doi:10.1039/C6CS00324A. 
[38] J.A. Williams, KEYS TO BIOREACTOR SELECTIONS, Chem. Eng. Prog. 98 (2002) 34-41.

[39] P.F. Stanbury, A. Whitaker, S.J. Hall, Design of a fermenter, in: P.F. Stanbury, A. Whitaker, S.J. Hall (Eds.), Princ. Ferment. Technol. (Third Ed., Third Edit, Butterworth-Heinemann, Oxford, 2017: pp. 401-485. doi:https://doi.org/10.1016/B978-0-08-099953-1.00007-7.

[40] M. Yasin, Y. Jeong, S. Park, J. Jeong, E.Y. Lee, R.W. Lovitt, B.H. Kim, J. Lee, I.S. Chang, Microbial synthesis gas utilization and ways to resolve kinetic and mass-transfer limitations, Bioresour. Technol. 177 (2015) 361-374. doi:10.1016/j.biortech.2014.11.022.

[41] A. Lapin, U. Hannover, NUMERICAL SIMULATION TWO-PHASE FLOWS THE DYNAMICS OF IN BUBBLE, Chem. Eng. Sci. 49 (1994) 3661-3674.

[42] P.M. Doran, Reactor Engineering, in: P.M. Doran (Ed.), Bioprocess Eng. Princ. (Second Ed., Second Edi, Academic Press, London, 2013: pp. 761-852. doi:https://doi.org/10.1016/B978-0-12-2208515.00014-9.

[43] J.C. Merchuk, C. Garcia, Bioreactors, Airlift Reactors, Encycl. Ind. Biotechnol. (2010) 851-912. doi:10.1002/9780470054581.eib144.

[44] C.Y. Feng, K.C. Khulbe, T. Matsuura, A.F. Ismail, Recent progresses in polymeric hollow fiber membrane preparation, characterization and applications, Sep. Purif. Technol. 111 (2013) 43-71. doi:10.1016/j.seppur.2013.03.017.

[45] N.S.A. Mutamim, Z.Z. Noor, M.A.A. Hassan, A. Yuniarto, G. Olsson, Membrane bioreactor: Applications and limitations in treating high strength industrial wastewater, Chem. Eng. J. 225 (2013) 109-119. doi:10.1016/j.cej.2013.02.131.

[46] L.G. Shen, Q. Lei, J.R. Chen, H.C. Hong, Y.M. He, H.J. Lin, Membrane fouling in a submerged membrane bioreactor: Impacts of floc size, Chem. Eng. J. 269 (2015) 328-334. 
doi:10.1016/j.cej.2015.02.002.

[47] M. Aslam, A. Charfi, G. Lesage, M. Heran, J. Kim, Membrane bioreactors for wastewater treatment: A review of mechanical cleaning by scouring agents to control membrane fouling, Chem. Eng. J. 307 (2017) 897-913. doi:10.1016/j.cej.2016.08.144.

[48] J. Dolina, O. Dlask, T. Lederer, L. Dvořák, Mitigation of membrane biofouling through surface modification with different forms of nanosilver, Chem. Eng. J. 275 (2015) 125-133. doi:10.1016/j.cej.2015.04.008.

[49] S. Chang, Application of submerged hollow fiber membrane in membrane bioreactors: Filtration principles, operation, and membrane fouling, Desalination. 283 (2011) 31-39. doi:https://doi.org/10.1016/j.desal.2011.03.025.

[50] P.H. Lee, S.Q. Ni, S.Y. Chang, S. Sung, S.H. Kim, Enhancement of carbon monoxide mass transfer using an innovative external hollow fiber membrane (HFM) diffuser for syngas fermentation: Experimental studies and model development, Chem. Eng. J. 184 (2012) 268-277. doi:10.1016/j.cej.2011.11.103.

[51] A. Silva-Teira, A. Sánchez, D. Buntner, L. Rodríguez-Hernández, J.M. Garrido, Removal of dissolved methane and nitrogen from anaerobically treated effluents at low temperature by MBR posttreatment, Chem. Eng. J. 326 (2017) 970-979. doi:10.1016/j.cej.2017.06.047.

[52] A. Kumar, J. Dewulf, H. Van Langenhove, Membrane-based biological waste gas treatment, Chem. Eng. J. 136 (2008) 82-91. doi:10.1016/j.cej.2007.06.006.

[53] H.H.J. Cox, M.A. Deshusses, Biotrickling Filters, in: V.M.C. Kennes C. (Ed.), Bioreact. Waste Gas Treat., Springer, Dordrecht, 2001: pp. 99-131. doi:10.1007/978-94-017-0930-9_4.

[54] C.N. Satterfield, Trickle-bed reactors, AIChE J. 21 (1975) 209-228. doi:10.1002/aic.690210202. 
[55] R. Iranpour, H.H.J. Cox, M.A. Deshusses, E.D. Schroeder, Literature review of air pollution control biofilters and biotrickling filters for odor and volatile organic compound removal, Environ. Prog. 24 (2005) 254-267. doi:10.1002/ep.10077.

[56] D.S. Parker, T. Jacobs, E. Bower, D.W. Stowe, G. Farmer, Maximizing trickling filter nitrification rates through biofilm control: Research review and full scale application, Water Sci. Technol. 36 (1997) 255-262. doi:10.1016/S0273-1223(97)00332-6.

[57] S. Kim, M.A. Deshusses, Understanding the limits of H2S degrading biotrickling filters using a differential biotrickling filter, Chem. Eng. J. 113 (2005) 119-126. doi:10.1016/j.cej.2005.05.001.

[58] E.L. Pagans, X. Font, A. Sánchez, Biofiltration for ammonia removal from composting exhaust gases, Chem. Eng. J. 113 (2005) 105-110. doi:10.1016/j.cej.2005.03.004.

[59] W. Jiade, C. Jianmeng, Removal of dichloromethane from waste gases with a bio-contact oxidation reactor, Chem. Eng. J. 123 (2006) 103-107. doi:https://doi.org/10.1016/j.cej.2006.06.023.

[60] J.J. Orgill, H.K. Atiyeh, M. Devarapalli, J.R. Phillips, R.S. Lewis, R.L. Huhnke, A comparison of mass transfer coefficients between trickle-bed, hollow fiber membrane and stirred tank reactors, Bioresour. Technol. 133 (2013) 340-346. doi:10.1016/j.biortech.2013.01.124.

[61] P.C. Munasinghe, S.K. Khanal, Syngas fermentation to biofuel: Evaluation of carbon monoxide mass transfer and analytical modeling using a composite hollow fiber (CHF) membrane bioreactor, Bioresour. Technol. 122 (2012) 130-136. doi:10.1016/j.biortech.2012.03.053.

[62] P.C. Munasinghe, S.K. Khanal, Evaluation of hydrogen and carbon monoxide mass transfer and a correlation between the myoglobin-protein bioassay and gas chromatography method for carbon monoxide determination, RSC Adv. 4 (2014) 37575. doi:10.1039/C4RA04696J.

[63] P.C. Munasinghe, S.K. Khanal, Syngas fermentation to biofuel: Evaluation of carbon monoxide mass 
transfer coefficient (kLa) in different reactor configurations, Biotechnol. Prog. 26 (2010) 1616-1621. doi:10.1002/btpr.473.

[64] A.J. Ungerman, T.J. Heindel, Carbon monoxide mass transfer for syngas fermentation in a stirred tank reactor with dual impeller configurations, Biotechnol. Prog. 23 (2007) 613-620. doi:10.1021/bp060311z.

[65] M.R. Wilkins, H.K. Atiyeh, Microbial production of ethanol from carbon monoxide, Curr Opin Biotech. 22 (2011) 326-330. doi:10.1016/j.copbio.2011.03.005.

[66] H. Abubackar, M.C. Veiga, C. Kennes, Biological conversion of carbon monoxide: rich syngas or waste gases to bioethanol, Biofuels Bioprod Biorefining. 5 (2011) 93-114. doi:10.1002/bbb.256.

[67] D. Kennes, H. Abubackar, M. Diaz, M.C. Veiga, C. Kennes, Bioethanol production from biomass: carbohydrate vs syngas fermentation, J Chem Technol Biot. 91 (2016) 304-317. doi:10.1002/jctb.4842.

[68] Y.K. Kim, H. Lee, Use of magnetic nanoparticles to enhance bioethanol production in syngas fermentation, Bioresour. Technol. 204 (2016) 139-144. doi:10.1016/j.biortech.2016.01.001.

[69] H. Zhu, B.H. Shanks, D.W. Choi, T.J. Heindel, Effect of functionalized MCM41 nanoparticles on syngas fermentation, Biomass Bioenergy. 34 (2010) 1624-1627. doi:10.1016/j.biombioe.2010.06.008.

[70] H.N. Abubackar, M.C. Veiga, C. Kennes, Biological conversion of carbon monoxide to ethanol: Effect of $\mathrm{pH}$, gas pressure, reducing agent and yeast extract, Bioresour. Technol. 114 (2012) 518-522. doi:10.1016/j.biortech.2012.03.027.

[71] D.K. Kundiyana, M.R. Wilkins, P. Maddipati, R.L. Huhnke, Effect of temperature, pH and buffer presence on ethanol production from synthesis gas by "Clostridium ragsdalei"., Bioresour. Technol. 102 (2011) 5794-5799. doi:10.1016/j.biortech.2011.02.032. 
[72] B.E. Skidmore, R.A. Baker, D.R. Banjade, J.M. Bray, D.R. Tree, R.S. Lewis, Syngas fermentation to biofuels: Effects of hydrogen partial pressure on hydrogenase efficiency, Biomass Bioenergy. 55 (2013) 156-162. doi:10.1016/j.biombioe.2013.01.034.

[73] M.D. Bredwell, M.D. Telgenhoff, S. Barnard, R.M. Worden, Effect of surfactants on carbon monoxide fermentations by Butyribacterium methylotrophicum, Appl Biochem Biotech. 63-65 (1997) 637647. doi:10.1007/BF02920462.

[74] M. Yasin, S. Park, Y. Jeong, E. Lee, J. Lee, I. Chang, Effect of internal pressure and gas/liquid interface area on the CO mass transfer coefficient using hollow fibre membranes as a high mass transfer gas diffusing system for microbial syngas fermentation, Bioresour. Technol. 169 (2014) 637-643. doi:10.1016/j.biortech.2014.07.026.

[75] I.S. Chang, B.H. Kim, R.W. Lovitt, J.S. Bang, Effect of CO partial pressure on cell-recycled continuous CO fermentation by Eubacterium limosum KIST612, Process Biochem. 37 (2001) 411-421. doi:10.1016/S0032-9592(01)00227-8.

[76] J. Saxena, R.S. Tanner, Effect of trace metals on ethanol production from synthesis gas by the ethanologenic acetogen, Clostridium ragsdalei, J Ind Microbiol Biot. 38 (2011) 513-521. doi:10.1007/s10295-010-0794-6.

[77] D.K. Kundiyana, R.L. Huhnke, M.R. Wilkins, Effect of nutrient limitation and two-stage continuous fermentor design on productivities during "Clostridium ragsdalei" syngas fermentation, Bioresour. Technol. 102 (2011) 6058-6064. doi:10.1016/j.biortech.2011.03.020.

[78] S. Ramió-pujol, R. Ganigué, L. Bañeras, J. Colprim, Incubation at $25^{\circ} \mathrm{C}$ prevents acid crash and enhances alcohol production in Clostridium carboxidivorans P7, Bioresour. Technol. 192 (2015) 296303. doi:10.1016/j.biortech.2015.05.077. 
[79] J.L. Vega, G.M. Antorrena, E.C. Clausen, J.L. Gaddy, Study of gaseous substrate fermentations: Carbon monoxide conversion to acetate. 2. Continuous culture, Biotechnol Bioeng. 34 (1989) 785793. doi:10.1002/bit.260340608.

[80] J.L. Vega, E.C. Clausen, J.L. Gaddy, Study of gaseous substrate fermentations: carbon monoxide conversion to acetate. 1. Batch culture., (1989) 774-784. doi:10.1002/bit.260340607.

[81] W.H. Lorowitz, M.P. Bryant, Peptostreptococcus productus strain that grows rapidly with CO as the energy source., Appl Env. Microb. 47 (1984) 961-964.

[82] T. Ezaki, N.A. Li, Y. Hashimoto, H. Miura, H. Yamamoto, 16S Ribosomal DNA Sequences of Anaerobic Cocci and Proposal of Ruminococcus hansenii comb. nov. and Ruminococcus productus comb. nov., Int. J. Syst. Evol. Microbiol. 44 (1994) 130-136.

http://ijs.microbiologyresearch.org/content/journal/ijsem/10.1099/00207713-44-1-130.

[83] C. Liu, S.M. Finegold, Y. Song, P.A. Lawson, Reclassification of Clostridium coccoides, Ruminococcus hansenii, Ruminococcus hydrogenotrophicus, Ruminococcus luti, Ruminococcus productus and Ruminococcus schinkii as Blautia coccoides gen. nov., comb. nov., Blautia hansenii comb. nov., Blautia hydroge, Int. J. Syst. Evol. Microbiol. 58 (2008) 1896-1902. http://ijs.microbiologyresearch.org/content/journal/ijsem/10.1099/ijs.0.65208-0.

[84] A.J. Grethlein, R.M. Worden, M.K. Jain, R. Datta, Continuous production of mixed alcohols and acids from carbon monoxide, Appl. Biochem. Biotechnol. 24-25 (1990) 875-884. doi:10.1007/BF02920301.

[85] R.M. Worden, A.J. Grethlein, J.G. Zeikus, R. Datta, Butyrate Production from Carbon Monoxide by Butyribacteriurn methylotrophicurn, Appl. Biochem. Biotechnol. 20 (1989) 687-699.

[86] J.G. Zeikus, L.H. Lynd, T.E. Thompson, J.A. Krzycki, P.J. Weimer, P.W. Hegge, Isolation and 
characterization of a new, methylotrophic, acidogenic anaerobe, the marburg strain, Curr Microbiol. 3 (1980) 381-386. doi:10.1007/BF02601907.

[87] L. Lynd, R. Kerby, J.G. Zeikus, Carbon monoxide metabolism of the methylotrophic acidogen Butyribacterium methylotrophicum., J Bacteriol. 149 (1982) 255-263.

[88] M.D. Bredwell, R.M. Worden, Mass-transfer properties of microbubbles. 1. Experimental studies, Biotechnol. Prog. 14 (1998) 31-38. doi:10.1021/bp970133x.

[89] M.R. Worden, M.D. Bredwell, Mass-Transfer Properties of Microbubbles. 2. Analysis Using a Dynamic Model, Biotechnol Progr. 14 (1998) 39-46. doi:10.1021/bp970131c.

[90] A.M. Henstra, J. Sipma, A. Rinzema, A.J.M. Stams, Microbiology of synthesis gas fermentation for biofuel production, Curr. Opin. Biotechnol. 18 (2007) 200-206. doi:10.1016/j.copbio.2007.03.008.

[91] H. Richter, M.E. Martin, L.T. Angenent, A two-stage continuous fermentation system for conversion of syngas into ethanol, Energies. 6 (2013) 3987-4000. doi:10.3390/en6083987.

[92] M. Mohammadi, H. Younesi, G. Najafpour, A.R. Mohamed, Sustainable ethanol fermentation from synthesis gas by Clostridium ljungdahlii in a continuous stirred tank bioreactor, J. Chem. Technol. Biotechnol. 87 (2012) 837-843. doi:10.1002/jctb.3712.

[93] H. Younesi, G. Najafpour, A.R. Mohamed, Liquid fuel production from synthesis gas via fermentation process in a continuous tank bioreactor ( CSTBR ) using Clostridium ljungdahlii, Iran. J. Biotechnol. 4 (2006) 45-53.

[94] Y. Shen, R. Brown, Z. Wen, Syngas fermentation of Clostridium carboxidivoran P7 in a hollow fiber membrane biofilm reactor: Evaluating the mass transfer coefficient and ethanol production performance, Biochem. Eng. J. 85 (2014) 21-29. doi:10.1016/j.bej.2014.01.010.

[95] Y. Shen, R. Brown, Z. Wen, Enhancing mass transfer and ethanol production in syngas fermentation 
of Clostridium carboxidivorans P7 through a monolithic biofilm reactor, Appl. Energy. 136 (2014) 6876. doi:10.1016/j.apenergy.2014.08.117.

[96] Y. Shen, R.C. Brown, Z. Wen, Syngas fermentation by Clostridium carboxidivorans P7 in a horizontal rotating packed bed biofilm reactor with enhanced ethanol production, Appl. Energy. 187 (2017) 585-594. doi:10.1016/j.apenergy.2016.11.084.

[97] J.L. Vega, S. Prieto, B.B. Elmore, E.C. Clausen, J.L. Gaddy, The Biological production of ethanol from synthesis gas, Appl. Biochem. Biotechnol. 20-21 (1989) 781-797. doi:10.1007/BF02936525.

[98] M. Devarapalli, H.K. Atiyeh, J.R. Phillips, R.S. Lewis, R.L. Huhnke, Ethanol production during semicontinuous syngas fermentation in a trickle bed reactor using Clostridium ragsdalei., Bioresour. Technol. 209 (2016) 56-65. doi:10.1016/j.biortech.2016.02.086.

[99] H.N. Abubackar, M.C. Veiga, C. Kennes, Carbon monoxide fermentation to ethanol by Clostridium autoethanogenum in a bioreactor with no accumulation of acetic acid, Bioresour. Technol. 186 (2015) 122-127. doi:10.1016/j.biortech.2015.02.113.

[100] P. Maddipati, H.K. Atiyeh, D.D. Bellmer, R.L. Huhnke, Ethanol production from syngas by Clostridium strain P11 using corn steep liquor as a nutrient replacement to yeast extract, Bioresour. Technol. 102 (2011) 6494-6501. doi:10.1016/j.biortech.2011.03.047.

[101] M. Devarapalli, R.S. Lewis, H.K. Atiyeh, Continuous Ethanol Production from Synthesis Gas by Clostridium ragsdalei in a Trickle-Bed Reactor, Fermentation. 3 (2017) 1-13. doi:10.3390/fermentation3020023.

[102] C. Kantzow, A. Mayer, D. Weuster-Botz, Continuous gas fermentation by Acetobacterium woodii in a submerged membrane reactor with full cell retention, J. Biotechnol. 212 (2015) 11-18. doi:10.1016/j.jbiotec.2015.07.020. 
[103] E.J. Wolfrum, A.S. Watt, Bioreactor design studies for noval hydrogen-producing bacterium, Appl. Biochem. Biotechnol. 98 (2002).

[104] P. Dürre, Biobutanol: An attractive biofuel, Biotechnol. J. 2 (2007) 1525-1534. doi:10.1002/biot.200700168.

[105] Y.S. Jang, J. Lee, A. Malaviya, D.Y. Seung, J.H. Cho, S.Y. Lee, Butanol production from renewable biomass: Rediscovery of metabolic pathways and metabolic engineering, Biotechnol. J. 7 (2012) 186-198. doi:10.1002/biot.201100059.

[106] Y.-S. Jang, A. Malaviya, C. Cho, J. Lee, S. Lee, Butanol production from renewable biomass by clostridia, Bioresour. Technol. 123 (2012) 653-663. doi:10.1016/j.biortech.2012.07.104.

[107] V. Berzin, M. Tyurin, M. Kiriukhin, Selective n-Butanol Production by Clostridium sp. MTButOH1365 During Continuous Synthesis Gas Fermentation Due to Expression of Synthetic Thiolase, 3-Hydroxy Butyryl-CoA Dehydrogenase, Crotonase, Butyryl-CoA Dehydrogenase, Butyraldehyde Dehydrog, Appl Biochem Biotech. 169 (2013) 950-959. doi:10.1007/s12010-012-0060-7.

[108] J. Wang, X. Yang, C.-C. Chen, S.-T. Yang, Engineering clostridia for butanol production from biorenewable resources: from cells to process integration, Curr Opin Chem Eng. 6 (2014) 43-54. doi:10.1016/j.coche.2014.09.003.

[109] S.-H. Lee, E. Yun, J. Kim, S. Lee, Y. Um, K. Kim, Biomass, strain engineering, and fermentation processes for butanol production by solventogenic clostridia, Appl Microbiol Biot. 100 (2016) 82558271. doi:10.1007/s00253-016-7760-9.

[110] F.-N. Ánxela, H. Abubackar, M.C. Veiga, C. Kennes, Carbon monoxide bioconversion to butanolethanol by Clostridium carboxidivorans: kinetics and toxicity of alcohols, Appl Microbiol Biot. 100 (2016) 4231-4240. doi:10.1007/s00253-016-7389-8. 
[111] X. Chen, B.-J. Ni, Anaerobic conversion of hydrogen and carbon dioxide to fatty acids production in a membrane biofilm reactor: A modeling approach, Chem Eng J. 306 (2016) 1092-1098. doi:10.1016/j.cej.2016.08.049.

[112] N. Li, J. Yang, C. Chai, S. Yang, W. Jiang, Y. Gu, Complete genome sequence of Clostridium carboxidivorans P7T, a syngas-fermenting bacterium capable of producing long-chain alcohols, J Biotechnol. 211 (2015) 44-45. doi:10.1016/j.jbiotec.2015.06.430.

[113] G. Bruant, M.-J. Lévesque, C. Peter, S.R. Guiot, L. Masson, Genomic Analysis of Carbon Monoxide Utilization and Butanol Production by Clostridium carboxidivorans Strain P7T, PLoS One. 5 (2010) e13033. doi:10.1371/journal.pone.0013033.

[114] M.N. Ukpong, H.K. Atiyeh, M. Lorme, K. Liu, X. Zhu, R.S. Tanner, M.R. Wilkins, B.S. Stevenson, Physiological response of Clostridium carboxidivorans during conversion of synthesis gas to solvents in a gas-fed bioreactor, Biotechnol Bioeng. 109 (2012) 2720-2728. doi:10.1002/bit.24549.

[115] J.R. Phillips, H.K. Atiyeh, R.S. Tanner, J.R. Torres, J. Saxena, M.R. Wilkins, R.L. Huhnke, Butanol and hexanol production in Clostridium carboxidivorans syngas fermentation: Medium development and culture techniques, Bioresour. Technol. 190 (2015) 114-121. doi:10.1016/j.biortech.2015.04.043.

[116] Á. Fernández-Naveira, H.N. Abubackar, M.C. Veiga, C. Kennes, Efficient butanol-ethanol (B-E) production from carbon monoxide fermentation by Clostridium carboxidivorans, Appl. Microbiol. Biotechnol. (2016) 3361-3370. doi:10.1007/s00253-015-7238-1.

[117] K. Liu, H.K. Atiyeh, B.S. Stevenson, R.S. Tanner, M.R. Wilkins, R.L. Huhnke, Continuous syngas fermentation for the production of ethanol, n-propanol and n-butanol, Bioresour. Technol. 151 (2014) 69-77. doi:10.1016/j.biortech.2013.10.059.

[118] K. Liu, H.K. Atiyeh, B.S. Stevenson, R.S. Tanner, M.R. Wilkins, R.L. Huhnke, Mixed culture syngas 
fermentation and conversion of carboxylic acids into alcohols, Bioresour. Technol. 152 (2014) 337346. doi:10.1016/j.biortech.2013.11.015.

[119] H. Richter, B. Molitor, M. Diender, D.Z. Sousa, L.T. Angenent, A Narrow pH Range Supports Butanol, Hexanol, and Octanol Production from Syngas in a Continuous Co-culture of Clostridium ljungdahlii and Clostridium kluyveri with In-Line Product Extraction, Front. Microbiol. 7 (2016) 1773. doi:10.3389/fmicb.2016.01773.

[120] M. Diender, A.J.M. Stams, D.Z. Sousa, Production of medium - chain fatty acids and higher alcohols by a synthetic co - culture grown on carbon monoxide or syngas, Biotechnol. Biofuels. (2016) 1-11. doi:10.1186/s13068-016-0495-0.

[121] D.L. Wise, C.L. Cooney, D.C. Augenstein, Biomethanation: Anaerobic fermentation of CO2, H2 and CO to methane, Biotechnol. Bioeng. 20 (1978) 1153-1172. doi:10.1002/bit.260200804.

[122] R.K. Thauer, A. Kaster, H. Seedorf, W. Buckel, Methanogenic archaea: ecologically relevant differences in energy conservation, Nat. Rev. Microbiol. 6 (2008) 579-591. doi:10.1038/nrmicro1931

[123] M.P. Bryant, M. BC, R.S. Wolfe, Hydrogen-oxidizing methane bacteria. I. Cultivation and methanogenesis., J Bacteriol. 95 (1968) 1118-1123.

[124] D.L. Wise, G. Houghton, Diffusion coefficients of neon, krypton, xenon, carbon monoxide and nitric oxide in water at 10-60 ${ }^{\circ} \mathrm{C}$, Chem. Eng. Sci. 23 (1968) 1211-1216. doi:10.1016/0009-2509(68)890293.

[125] K.T. Klasson, J.P. Cowger, C.W. Ko, J.L. Vega, E.C. Clausen, J.L. Gaddy, Methane Production from Synthesis Gas Using a Mixed Culture of R . rubrum , M . barkeri , and M . formicicum, Appl. Biochem. Biotechnol. 24 (1990) 317-328. 
[126] D.E. Kimmel, K.T. Klasson, E.C. Clausen, J.L. Gaddy, Performance of Trickle-Bed Bioreactors for Converting Synthesis Gas to Methane, Appl. Biochem. Biotechnol. 28 (1991) 457-469.

[127] M. Burkhardt, T. Koschack, G. Busch, Biocatalytic methanation of hydrogen and carbon dioxide in an anaerobic three-phase system., Bioresour. Technol. 178 (2015) 330-333. doi:10.1016/j.biortech.2014.08.023.

[128] S.R. Guiot, R. Cimpoia, G. Carayon, Potential of wastewater-treating anaerobic granules for biomethanation of synthesis gas, Environ. Sci. Technol. 45 (2011) 2006-2012. doi:10.1021/es102728m.

[129] G. Luo, W. Wang, I. Angelidaki, Anaerobic digestion for simultaneous sewage sludge treatment and CO biomethanation: process performance and microbial ecology., Environ. Sci. Technol. 47 (2013) 10685-93. doi:10.1021/es401018d.

[130] S. Westman, K. Chandolias, M. Taherzadeh, Syngas Biomethanation in a Semi-Continuous Reverse Membrane Bioreactor (RMBR), Fermentation. 2 (2016) 8. doi:10.3390/fermentation2020008.

[131] P. Hu, S. Chakraborty, A. Kumar, B.M. Woolston, H. Liu, D. Emerson, G. Stephanopoulos, Integrated Bioprocess for Conversion of Gaseous Substrates to Liquids, Proc. Natl. Acad. Sci. 113 (2016) 14-19. doi:10.1073/pnas.1516867113.

[132] P. Hu, H. Rismani-Yazdi, G. Stephanopoulos, Anaerobic CO 2 fixation by the acetogenic bacterium Moorella thermoacetica, AIChE J. 59 (2013) 3176-3183. doi:10.1002/aic.14127.

[133] L.B. Brentner, J. Peccia, J.B. Zimmerman, Challenges in Developing Biohydrogen as a Sustainable Energy Source: Implications for a Research Agenda, Env. Sci Technol. 44 (2010) 2243-2254. doi:10.1021/es9030613.

[134] S. Rittmann, H. Lee, J. Lim, T. Kim, J.-H. Lee, S. Kang, One-carbon substrate-based biohydrogen 
production: Microbes, mechanism, and productivity, Biotechnol Adv. 33 (2015) 165-177. doi:10.1016/j.biotechadv.2014.11.004.

[135] H. Younesi, G. Najafpour, K.S. Ku Ismail, A.R. Mohamed, A.H. Kamaruddin, Biohydrogen production in a continuous stirred tank bioreactor from synthesis gas by anaerobic photosynthetic bacterium: Rhodopirillum rubrum, Bioresour. Technol. 99 (2008) 2612-2619. doi:10.1016/j.biortech.2007.04.059.

[136] K.T. Klasson, A. Gupta, E.C. Clausen, J.L. Gaddy, Evaluation of Mass-Transfer and Kinetic Parameters for Rhodospirillum rubrurn in a Continuous Stirred Tank Reactor, Appl. Biochem. Biotechnol. 39 (1993) 549-557.

[137] Y. Zhao, M. Haddad, R. Cimpoia, Z. Liu, S.R. Guiot, Performance of a Carboxydothermus hydrogenoformans - immobilizing membrane reactor for syngas upgrading into hydrogen, Int. J. Hydrogen Energy. 38 (2012) 2167-2175. doi:10.1016/j.ijhydene.2012.11.038.

[138] M. Haddad, R. Cimpoia, S.R. Guiot, Performance of Carboxydothermus hydrogenoformans in a gaslift reactor for syngas upgrading into hydrogen, Int. J. Hydrogen Energy. 39 (2013) 2543-2548. doi:10.1016/j.ijhydene.2013.12.022.

[139] Y.-K. Oh, Y.-J. Kim, J.-Y. Park, T.H. Lee, M.-S. Kim, S. Park, Biohydrogen production from carbon monoxide and water byRhodopseudomonas palustris P4, Biotechnol. Bioprocess Eng. 10 (2005) 270. doi:10.1007/BF02932024.

[140] G.Y. Jung, J.R. Kim, J.-Y. Park, S. Park, Hydrogen production by a new chemoheterotrophic bacterium Citrobacter sp. Y19, Int. J. Hydrogen Energy. 27 (2002) 601-610. doi:https://doi.org/10.1016/S03603199(01)00176-8.

[141] M.-S. Kim, S.S. Bae, Y.J. Kim, T.W. Kim, J.K. Lim, S.H. Lee, A.R. Choi, J.H. Jeon, J.-H. Lee, H.S. Lee, S.G. 
Kang, CO-Dependent H(2) Production by Genetically Engineered Thermococcus onnurineus NA1, Appl. Environ. Microbiol. 79 (2013) 2048-2053. doi:10.1128/AEM.03298-12.

[142] Ineos Bio Technology Platform, (2016). http://www.ineos.com/businesses/ineos-bio/technology (accessed May 30, 2016).

[143] E. Voegele, Ineos Bio to sell ethanol business, including Vero Beach plant, (2016). http://biomassmagazine.com/articles/13662/ineos-bio-to-sell-ethanol-business-including-verobeach-plant (accessed July 12, 2017).

[144] Alliance Bio-Products gains USDA approval to buy Ineos Bio plant, (2017). http://www.biomassmagazine.com/articles/14517/alliance-bio-products-gains-usda-approval-tobuy-ineos-bio-plant (accessed July 12, 2017).

[145] LanzaTech, (2016). http://www.lanzatech.com/ (accessed May 30, 2016).

[146] Coskata's technology re-emerges as Synata Bio, (2016). http://www.biofuelsdigest.com/bdigest/2016/01/24/coskatas-technology-re-emerges-as-synatabio/ (accessed July 12, 2017). 